See discussions, stats, and author profiles for this publication at: https://www.researchgate.net/publication/319837600

\title{
New Fluorinated Dithienyldiketopyrrolopyrrole Monomers and Polymers for Organic Electronics
}

Article in Macromolecules · September 2017

DOI: 10.1021/acs.macromol.7b01198

CITATIONS

37

10 authors, including:

Thomas Bura

Laval University

45 PUBLICATIONS 2,390 CITATIONS

SEE PROFILE

Olzhas Ibraikulov

CEA Tech

21 PUBLICATIONS 319 CITATIONS

SEE PROFILE

Some of the authors of this publication are also working on these related projects:

Polymer Solar cells View project

Unipolarization View project
311

Serge Beaupre

Laval University

76 PUBLICATIONS 10,152 CITATIONS

SEE PROFILE

2. Marc-André Légaré

McGill University

41 PUBLICATIONS 2,499 CITATIONS

SEE PROFILE 


\title{
New Fluorinated Dithienyldiketopyrrolopyrrole Monomers and Polymers for Organic Electronics
}

\author{
Thomas Bura, ${ }^{\dagger}$ Serge Beaupré, ${ }^{\dagger}$ Olzhas A. Ibraikulov, ${ }^{\ddagger}$ Marc-André Légaré, ${ }^{\S}$ Jesse Quinn,,
} Patrick Lévêque, ${ }^{\ddagger}$ Thomas Heiser, ${ }^{\ddagger}$ Yuning Li, ${ }^{\| \odot}$ Nicolas Leclerc, ${ }^{\perp}$ and Mario Leclerc ${ }^{*}, \oplus$

${ }^{\dagger}$ Canada Research Chair on Electroactive and Photoactive Polymers, Department of Chemistry, Université Laval, Quebec City, Quebec G1V 0A6, Canada

${ }^{\ddagger}$ Laboratoire ICube, DESSP, Université de Strasbourg, CNRS, 23 rue du Loess, Strasbourg 67037, France

${ }^{\S}$ Institut für Anorganische Chemie, Julius-Maximilians Universität Würzburg, Am Hubland, Würzburg 97074, Germany

"Department of Chemical Engineering, University of Waterloo, Waterloo, Ontario N2L 3G1, Canada

${ }^{\perp}$ Institut de Chimie et Procédés pour l'Énergie, l'Environnement et la Santé, ICPEES, Université de Strasbourg, CNRS, Strasbourg 67087, France

\section{Supporting Information}

ABSTRACT: Diketopyrrolopyrrole (DPP) derivatives are among the most efficient materials studied for both polymer solar cells (PSCs) and organic field-effect transistors (OFETs) applications. We report here the synthesis of new fluorinated dithienyldiketopyrrolopyrrole (fDT-DPP) monomers suitable for direct heteroarylation polymerization. fDT-DPP copolymers were then prepared to probe the effect of the fluorination. It was found that they feature deeper HOMO energy levels and smaller bandgaps than their non-fluorinated analogues. Moreover, some fDT-DPP copolymers show ambipolar behavior when tested in OFETs. For example, P2 shows hole mobility up to $0.8 \mathrm{~cm}^{2} \mathrm{~V}^{-1} \mathrm{~s}^{-1}$ and electron mobility up to $0.5 \mathrm{~cm}^{2} \mathrm{~V}^{-1} \mathrm{~s}^{-1}$. Inverted PSCs with power conversion efficiency (PCE) up to $7.5 \%$ were also obtained for P5. These results reported here (OFETs and PSCs) confirm that the fluorination of dithienyl-DPP moieties improves the performance of organic electronics devices. This study is also evidencing the strength of the direct heteroarylation polymerization and fDT-DPP as a new class of conjugated polymers.

\section{INTRODUCTION}

In the past few years, organic solar cells (OSCs) and organic field-effect transistors (OFETs) based on $\pi$-conjugated polymers have stimulated broad interest from academic and industrial laboratories due to the possibility of creating efficient, lightweight, and flexible devices using inexpensive and environmentally friendly solution-based printing techniques. ${ }^{1-6}$ Tuning of the physical and electro-optical properties of conjugated polymers through chemical modification of their backbone has led to a wide array of promising materials for organic electronics applications. Indeed, with polymer solar cells (PSCs) exhibiting power conversion efficiency (PCE) exceeding $10 \%,{ }^{7-10}$ OFETs with hole mobility up to $20 \mathrm{~cm}^{2} \mathrm{~V}^{-1} \mathrm{~s}^{-1},{ }^{11}$ and electron mobility as high as $7.0 \mathrm{~cm}^{2} \mathrm{~V}^{-1} \mathrm{~s}^{-1,12}$ conjugated polymers now show performance suitable for commercial applications. Among all the new electroactive and photoactive materials developed over the past 20 years, 2,5-dihydropyrrolo[3,4-c]pyrrole-1,4-dione (DPP)-based polymers have been found especially valuable since they deliver high performances in both PSCs and OFETs. For example, PDPPTT, a copolymer based on dithienyl-DPP and thieno[3,2-b] thiophene (TT), showed PCE up to $9.4 \%{ }^{13}$ and hole mobility up to $10.5 \mathrm{~cm}^{2}$
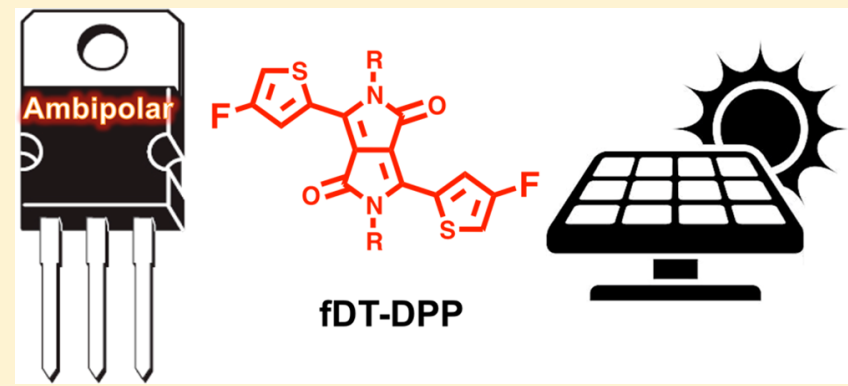

fDT-DPP
$\mathrm{V}^{-1} \mathrm{~s}^{-1} \cdot{ }^{14}$ Since the first report on the synthesis of 3,6diphenyl-DPP by Farnum et al. in 1974, ${ }^{15}$ the synthesis and the modulation of the electro-optical properties of DPP copolymers have been extensively studied and reviewed. ${ }^{16-27}$ The flanking aromatic substituents (five- or six-membered-fused or unfused heterocyclic rings) strongly modulate the electro-optical properties. Flanking thiophenes, a five-membered ring, notably have minimal steric effects on the DPP core and lead to coplanar dithienyl-DPP building blocks that are widely used in conjugated polymers. Recently, fluorination of conjugated backbone of $\mathrm{D}-\mathrm{A}$ copolymers has proven to be effective to enhance the properties of PSC and OFETs. ${ }^{28}$ The strong electronegativity of fluorine effectively lowers both the HOMO and LUMO energy levels of the fluorinated copolymers without perturbing the planarity of the backbone, thanks to its small van der Waals radius $(r=0.135 \mathrm{~nm})$. In addition, changes in crystallinity, internal polarization, and morphology of the active layer have also been attributed to fluorination. Up to now, the

Received: June 8, 2017

Revised: September 6, 2017 
Scheme 1. Monomers and Polymers Investigated in This Work

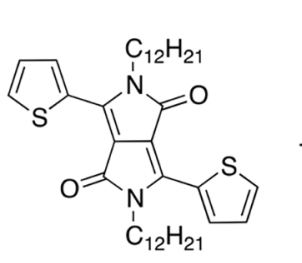

M3

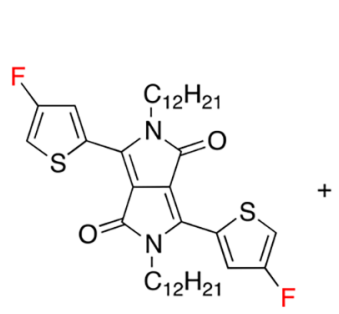

M6

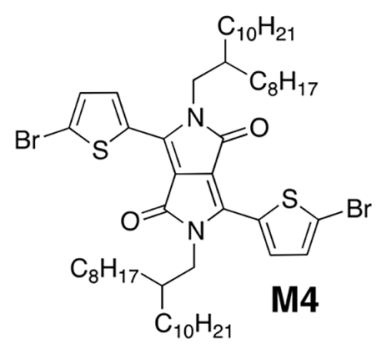

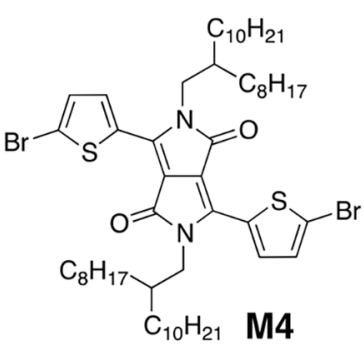

M4

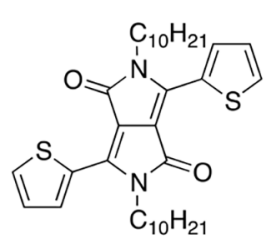

M2<smiles>[10CH3]C([18F])n1c2cc(Br)ccc2c2ccc(Br)cc21</smiles>

M1

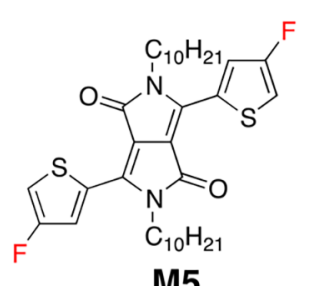

M5<smiles>[10BH]C([18F])n1c2cc(Br)ccc2c2ccc(Br)cc21</smiles>

M1

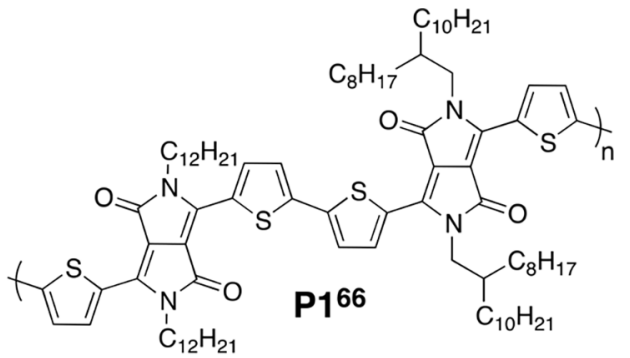

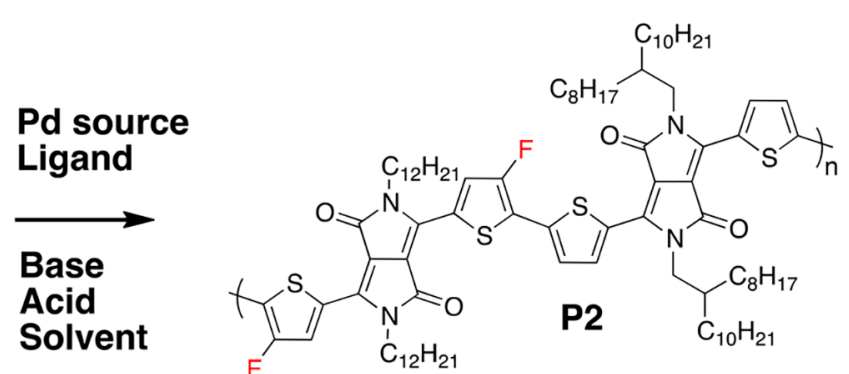

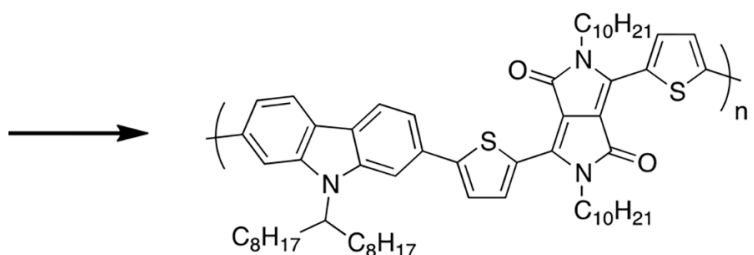

P3

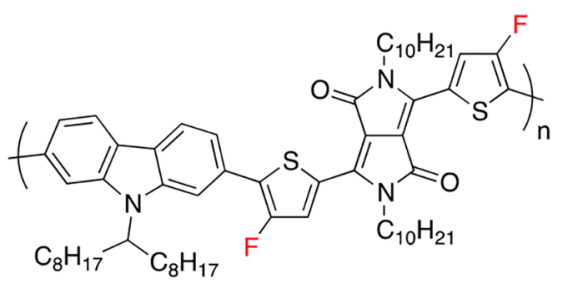

P4 \& P5 best-performing semiconducting polymers incorporate fluorine atoms in their chemical structure. ${ }^{29-33}$ It is believed that fDTDPP is capable to induce ambipolarity in OFETs, which is specifically attractive for the fabrication of single-semiconductor complementary metal-oxide-semiconductor (CMOS) inverters and light-emitting devices. ${ }^{34-40}$ A single organic semiconductor would facilitate the fabrication of CMOS inverters, and the devices are much more stable in comparison to the semiconductor blends and/or double-layer semiconductor films, which have demonstrated difficulties related to nanomorphological formation in the blended films or coalescing of the bilayers. ${ }^{41}$ Ambipolar polymers based on electron acceptors of naphthalenediimide (NDI), ${ }^{42-45}$ benzodifurandione, ${ }^{46-49}$ isoindigo (IID),,$^{50-52}$ and diketopyrrolopyrrole (DPP) $)^{53-60}$ or its derivatives ${ }^{61,62}$ have been reported; however, there are still only a small number of polymeric semiconductors that display ambipolar characteristics with high and balanced hole and electron mobilities. ${ }^{63}$

Along these lines, we report for the first time an efficient and reliable procedure for the synthesis of pure 4-fluoro-2thiophenecarbonitrile, a pivotal component for the synthesis of fluorinated dithienodiketopyrrolopyrrole (fDT-DPP) (Scheme 1). Unlike the work reported by Jiang et al. on
fluorodiphenyl-DPP (fDP-DPP), ${ }^{64}$ we found that the synthesis of fDT-DPP proceeded smoothly using the well-established succinate-based procedure. The fDT-DPP-based copolymers prepared by direct (hetero)arylation polymerization exhibit broad and red-shifted absorption in the UV-vis-NIR region with deeper HOMO energy levels compared to their nonfluorinated analogues. When tested in OFETs, a fDT-DPP copolymer shows an ambipolar behavior with both high hole and electron mobilities whereas other copolymers demonstrated highly interesting photovoltaic properties. Based on these results, fDT-DPP is a promising building block for organic electronics.

\section{EXPERIMENTAL SECTION}

2.1. Methods. ${ }^{1} \mathrm{H},{ }^{13} \mathrm{C}$, and ${ }^{19} \mathrm{~F}$ NMR spectra were recorded on a Varian AS400 or Agilent DD2 $500 \mathrm{MHz}$ apparatus in deuterated solvents. Chemical shifts were reported as $\delta$ values (ppm) relative to the residual protic solvent. The number-average $\left(\bar{M}_{\mathrm{n}}\right)$ and weightaverage $\left(\bar{M}_{\mathrm{w}}\right)$ molecular weights were determined by size exclusion chromatography (SEC) using a Malvern HT-GPC equipped with an $\mathrm{RI}$ detector. The flow rate was fixed at $0.75 \mathrm{~mL} / \mathrm{min}$ using $1,2,4-$ trichlorobenzene (TCB) (with $0.0125 \%$ BHT w/v) as the eluent. The temperature of the system was set to $140{ }^{\circ} \mathrm{C}$. All the samples were prepared at concentrations of nominally $0.50 \mathrm{mg} / \mathrm{mL}$ in TCB. The 
sample vials were held at $140{ }^{\circ} \mathrm{C}$ with stirring for $1 \mathrm{~h}$ for complete dissolution. The calibration method used to generate the reported data was the classical polystyrene method using polystyrene standards which were dissolved in TCB. UV-vis absorption spectra were taken using a Thermo Scientific Genesys $10 \mathrm{~S}$ spectrophotometer using $1 \mathrm{~cm}$ path-length quartz cells. For solid-state measurements, polymer solution was spun-cast on glass plates. Optical bandgaps were calculated from the onset of the absorption band. Cyclic voltammograms were recorded on a Solartron 1287 potentiostat using platinum wires as working electrode and counter electrode at a scan rate of 50 $\mathrm{mV} / \mathrm{s}$. The reference electrode was $\mathrm{Ag} / \mathrm{Ag}^{+}\left(0.01 \mathrm{M} \mathrm{AgNO}_{3}\right.$ in acetonitrile), and the electrolyte was a solution of $0.1 \mathrm{M}$ tetrabutylammonium hexafluorophosphate $\left(\mathrm{Bu}_{4} \mathrm{NPF}_{6}\right)$ in dry acetonitrile. In these conditions, the oxidation potential of ferrocene was $0.09 \mathrm{~V}$ versus $\mathrm{Ag} / \mathrm{Ag}^{+}$, whereas the oxidation potential of ferrocene was 0.41 $\mathrm{V}$ versus saturated calomel electrode (SCE). The HOMO and LUMO energy levels were determined from the oxidation and reduction onsets (where the current differs from the baseline) assuming that SCE electrode is $-4.71 \mathrm{eV}$ from vacuum, as reported in the literature. ${ }^{65}$ Thermogravimetric analysis (TGA) measurements were carried out with a Mettler Toledo TGA SDTA 851e apparatus at a heating rate of $10{ }^{\circ} \mathrm{C} / \mathrm{min}$ under a nitrogen atmosphere. The temperature of degradation $\left(T_{\mathrm{d}}\right)$ corresponds to a $5 \%$ weight loss. Differential scanning calorimetry (DSC) analyses were performed on a PerkinElmer DSC-7 instrument calibrated with ultrapure indium at a scanning rate of $10{ }^{\circ} \mathrm{C} / \mathrm{min}$ under a nitrogen flow. The WAXS diffraction (powder) measurements were done with a Krytalloflex 760 generator $(40 \mathrm{kV}, 40 \mathrm{~mA})$, a goniometer, and a two-dimensional HiStar detector. A sealed tube emitting at $1.5418 \AA$ (copper K $\alpha$ ) nickelfiltered was used as the source. GADDS software was used to control and to perform analysis of all experiments.

2.2. Fabrication and Testing of OFETs. Organic field effect transistors (OFETs) were fabricated on a heavily ${ }^{+2}$-doped $\mathrm{Si} / \mathrm{SiO}_{2}$ substrate with bottom-gate bottom-contact configuration (BGBC). The thermal grown $\mathrm{SiO}_{2}(\sim 300 \mathrm{~nm})$ was used as the gate dielectric and the conductive Si layer functioned as the gate. The gold source/ drain contact pairs with a channel length of $30 \mu \mathrm{m}$ and a channel width of $1000 \mu \mathrm{m}$ were obtained by conventional photolithography and thermal deposition. The substrate was then plasma treated and cleaned by ultrasonication with acetone and isopropanol, dried with nitrogen, and baked at $120^{\circ} \mathrm{C}$ for $1 \mathrm{~min}$. The substrate was then cooled to room temperature, dried, and submerged in a dodecyltrichlorosilane (DDTS) solution (3\% in toluene) for $20 \mathrm{~min}$ and then rinsed with toluene and dried with nitrogen. Subsequently, a polymer layer was deposited by spin-coating a polymer solution in $o$-dichlorobenzene ( $o$ DCB) $\left(10 \mathrm{mg} \mathrm{mL}^{-1}\right)$ at $3000 \mathrm{rpm}$ for $80 \mathrm{~s}$ in a glovebox. After annealing at a predetermined temperature in the glovebox filled with nitrogen for $20 \mathrm{~min}$, the devices were characterized in the same glovebox with an Agilent B2912A semiconductor analyzer. The mobility in the saturation region was calculated according to the equation

$$
I_{\mathrm{DS}}=\frac{W}{2 L} C_{j} \mu\left(V_{\mathrm{GS}}-V_{\mathrm{TH}}\right)^{2}
$$

where $I_{\mathrm{DS}}$ is the drain current, $W$ and $L$ are the device channel width and length, $C_{i}$ is the gate dielectric layer capacitance per unit area $\left(\sim 11.6 \mathrm{nF} \mathrm{cm}{ }^{-2}\right), \mu$ is the carrier mobility, and $V_{\mathrm{GS}}$ and $V_{\mathrm{TH}}$ are gate voltage and threshold voltage.

2.3. Fabrication and Testing of Hole-Only Space Charge Limited Current Devices. ITO-coated glass was utilized as a substrate. Substrates were cleaned consecutively in ultrasonic baths at $45{ }^{\circ} \mathrm{C}$ for $15 \mathrm{~min}$ using soapsuds, acetone, and isopropanol followed by $15 \mathrm{~min}$ UV-ozone treatment. A thin poly(ethylenedioxythiophene):polystyrenesulfonate (PEDOT:PSS) layer was spincoated onto precleaned ITO and used as a bottom electrode. Polymer and polymer:fullerene layers were spin-coated from hot solutions $\left(\approx 110^{\circ} \mathrm{C}\right)$ onto preheated substrates $\left(\approx 110^{\circ} \mathrm{C}\right)$. Devices were left overnight under high vacuum $\left(\approx 5 \times 10^{-7} \mathrm{mbar}\right)$ and were completed by thermally evaporated $\mathrm{MoO}_{3}(7 \mathrm{~nm}) / \mathrm{Ag}(120 \mathrm{~nm})$ layer. SCLC diode (surface area: $1 \mathrm{~mm}^{2}$ ) current-voltage characteristics were measured using a Keithley 4200 semiconductor characterization system.

2.4. Fabrication and Testing of Polymer Solar Cells. ITOcoated glass was utilized as a substrate. A $\mathrm{ZnO}$ layer $(\approx 20-25 \mathrm{~nm})$ was spin-coated from $\mathrm{ZnO}$ nanoparticles solution (Nanograde N10) onto precleaned ITO and thermally annealed at $100{ }^{\circ} \mathrm{C}$ for $10 \mathrm{~min}$ and used as an electron extracting electrode. Active layers were elaborated from $o-\mathrm{DCB}$ and $o-\mathrm{DCB} /$ additive (DIO/DPE) solutions using blends of polymers and $\mathrm{PC}_{71} \mathrm{BM}$ as an electron acceptor material at various weight ratios. The concentrations of solutions were $8 \mathrm{mg} / \mathrm{mL}$ with respect to polymer content. Top electrode consisting of $\mathrm{MoO}_{3}$ (7 $\mathrm{nm}) / \mathrm{Ag}(120 \mathrm{~nm})$ was thermally evaporated under $\approx 5 \times 10^{-7} \mathrm{mbar}$ vacuum. Four diodes with a $12 \mathrm{~mm}^{2}$ active area were elaborated per substrate. All characterization was done in nitrogen atmosphere under dark and simulated AM1.5G standard irradiation $\left(100 \mathrm{~mW} / \mathrm{cm}^{2}\right.$, Lot Oriel Sun 3000 solar simulator).

2.5. Materials. 2,3-Dibromothiophene (1) and $N$-fluorobenzenesulfonimide (NFSI) were purchased from Combiblocks. NFSI was recrystallized in diethyl ether prior to use. $n$-Octyldimethylchlorosilane was purchased from Gelest Inc. P1, ${ }^{66}$ 2,7-dibromo-9-(heptadecan-9yl)-9H-carbazole (M1), ${ }^{67}$ 3,6-bis(thiophen-2-yl)-2,5-bis(decyl)pyrrolo[3,4-c]pyrrole-1,4-dione (M2), ${ }^{68}$ 3,6-bis(thiophen-2-yl)-2,5bis(dodecyl)pyrrolo[3,4-c]pyrrole-1,4-dione (M3), ${ }^{66}$ 3,6-bis(5-bromothiophen-2-yl)-2,5-bis(2-octyldodecyl)pyrrolo[3,4-c]pyrrole-1,4)dione (M4), ${ }^{69}$ and tris(2-cycloheptyloxyphenyl)phosphine (BuraPhos ${ }^{70}$ were synthesized according to procedures reported in the literature.

2.6. Synthesis of Monomers. 2.6.1. Synthesis of 3-Bromo-2(dimethyloctylsilyl)thiophene (2). Compound 1 (12.33 g, 50.96 mmol, 1 eq.) was placed in a dried round-bottom flask with a magnetic stirrer and purged on a Schlenk line. Anhydrous diethyl ether (100 $\mathrm{mL}$ ) was added, and the solution was cooled to $-80{ }^{\circ} \mathrm{C}$ using an $\mathrm{Et}_{2} \mathrm{O} / \mathrm{N}_{2}$ cooling bath. Then, a solution of $n$ - BuLi ( $2.5 \mathrm{M}$ in hexanes, $20.4 \mathrm{~mL}, 50.96 \mathrm{mmol}, 1 \mathrm{eq}$.) was added dropwise, and the mixture was left to react for $20 \mathrm{~min}$ at $-80{ }^{\circ} \mathrm{C}$. After this time, $n$-octyldimethylchlorosilane $(13.5 \mathrm{~mL}, 56.05 \mathrm{mmol}, 1.1$ eq.) was added rapidly, and the reaction mixture was allowed to warm to room temperature and reacted overnight. The reaction was quenched with a saturated solution of $\mathrm{NH}_{4} \mathrm{Cl}$ and extracted three times with diethyl ether. The combined organic phases were washed with water and brine, dried over $\mathrm{MgSO}_{4}$, and concentrated under vacuum. Purification was achieved by vacuum distillation (bp $110-115{ }^{\circ} \mathrm{C}$ at $0.35 \mathrm{mmHg}$ ), affording the desired compound as colorless oil $(Y=85 \%) .{ }^{1} \mathrm{H}$ NMR $500 \mathrm{MHz}\left(\mathrm{CDCl}_{3}\right) \delta(\mathrm{ppm}): 7.45(\mathrm{~d}, J=4.8 \mathrm{~Hz}, 1 \mathrm{H}), 7.10(\mathrm{~d}, J=4.8$ $\mathrm{Hz}, 1 \mathrm{H}), 1.34-1.25$ (m, 12H), 0.91-0.86 (m, 5H), $0.38(\mathrm{~s}, 6 \mathrm{H}) .{ }^{13} \mathrm{C}$ NMR $126 \mathrm{MHz}\left(\mathrm{CDCl}_{3}\right) \delta(\mathrm{ppm}): 133.9,132.6,130.8,117.4,33.5$, 32.1, 29.4, 23.8, 22.8, 15.5, 14.3, -2.3 .

2.6.2. Synthesis of 3-Fluoro-2-(dimethyloctylsilyl)thiophene (3). 3-Bromo-2-(dimethyloctylsilyl)thiophene (2) (5.64 g, $16.9 \mathrm{mmol}, 1$ eq.) and TMEDA $(2.8 \mathrm{~mL}, 1.1$ eq.) were placed in a dried roundbottom flask with magnetic stirrer and then purged on a Schlenk line. Anhydrous THF $(180 \mathrm{~mL})$ was added, and the solution was cooled to $-100{ }^{\circ} \mathrm{C}$ in an $\mathrm{Et}_{2} \mathrm{O} / \mathrm{N}_{2}$ cooling bath. Freshly recrystallized NFSI (6.4 g, $20.3 \mathrm{mmol}, 1.2$ eq.) was solubilized in $60 \mathrm{~mL}$ of anhydrous THF in another round-bottom flask under argon and was also cooled to -100 ${ }^{\circ} \mathrm{C}$. $n$-BuLi (2.5 M in hexane, $2.8 \mathrm{~mL}, 17.75 \mathrm{mmol}, 1.05$ eq.) was added dropwise into the solution of 2 , which was left to react for $25 \mathrm{~min}$ at $-100{ }^{\circ} \mathrm{C}$. The NFSI solution was added rapidly to the organolithium mixture via a cannula while maintaining the low temperature of both flasks $\left(-100{ }^{\circ} \mathrm{C}\right)$. The reaction mixture was allowed to warm to room temperature and was left to react overnight. The reaction was quenched with a saturated solution of $\mathrm{NH}_{4} \mathrm{Cl}$ and extracted three times with hexanes. The combined organic phases were washed with water and brine, dried over $\mathrm{MgSO}_{4}$, and concentrated under vacuum. Purification was achieved by column chromatography (silica gel) with hexanes as eluent affording the desired compound as colorless oil $(Y=$ 65\%). ${ }^{1} \mathrm{H}$ NMR $500 \mathrm{MHz}$ (acetone- $\left.d_{6}\right) \delta(\mathrm{ppm}): 7.66(\mathrm{dd}, J=5.0 \mathrm{~Hz}$, $2.9 \mathrm{~Hz}, 1 \mathrm{H}), 6.95(\mathrm{dd}, J=5.0 \mathrm{~Hz}, 1.5 \mathrm{~Hz}, 1 \mathrm{H}), 1.40-1.27(\mathrm{~m}, 12 \mathrm{H})$, $0.87(\mathrm{t}, J=7.0 \mathrm{~Hz}, 3 \mathrm{H}), 0.83-0.80(\mathrm{~m}, 2 \mathrm{H}), 0.31(\mathrm{~s}, 6 \mathrm{H}) .{ }^{19} \mathrm{~F}$ NMR $470 \mathrm{MHz}$ (acetone- $\left.d_{6}\right) \delta$ (ppm): $-122.4 .{ }^{13} \mathrm{C}$ NMR $101 \mathrm{MHz}$ 
$\left(\mathrm{CDCl}_{3}\right) \delta(\mathrm{ppm}): 163.7(\mathrm{~d}, J=255.4 \mathrm{~Hz}), 129.8(\mathrm{~d}, J=8.6 \mathrm{~Hz})$, $118.2(\mathrm{~d}, J=31.3 \mathrm{~Hz}), 114.4(\mathrm{~d}, J=30.9), 33.5,32.1,29.4,23.8,22.8$, $16.2,14.3,-2.1$.

2.6.3. Synthesis of 4-Fluoro-5-(dimethyloctylsilyl)-2-thiophenecarboxaldehyde (4). Compound 3 (1.45 g, $5.31 \mathrm{mmol}, 1$ eq.) was placed in a dried round-bottom flask with a magnetic stirrer and purged on a Schlenk line. Anhydrous THF $(20 \mathrm{~mL})$ was added, and the solution was cooled to $-78{ }^{\circ} \mathrm{C}$. Then, a solution of $n-\mathrm{BuLi}(2.5 \mathrm{M}$ in hexanes, $2.35 \mathrm{~mL}, 5.84 \mathrm{mmol}, 1.1 \mathrm{eq}$.) was added dropwise, and the mixture was reacted for $20 \mathrm{~min}$ at $-78{ }^{\circ} \mathrm{C}$. Then, anhydrous DMF $(0.9$ $\mathrm{mL}, 10.6 \mathrm{mmol}, 2$ eq.) was added, and the reaction mixture was allowed to warm to room temperature and was left to react overnight. The reaction was quenched with a saturated solution of $\mathrm{NH}_{4} \mathrm{Cl}$ and extracted three times with diethyl ether. The combined organic phases were washed with water and brine, dried over $\mathrm{MgSO}_{4}$, and concentrated under vacuum. Purification was achieved by column chromatography (silica gel; ethyl acetate/hexanes 10/90 as eluent) affording the desired compound as colorless oil $(Y=80 \%) .{ }^{1} \mathrm{H}$ NMR $500 \mathrm{MHz}\left(\mathrm{CDCl}_{3}\right) \delta(\mathrm{ppm}): 9.80(\mathrm{~d}, J=0.4 \mathrm{~Hz}, 1 \mathrm{H}), 7.46(\mathrm{~d}, J=1.8$ $\mathrm{Hz}, 1 \mathrm{H}), 1.34-1.24(\mathrm{~m}, 12 \mathrm{H}), 0.87(\mathrm{t}, J=7.0 \mathrm{~Hz}), 0.83-0.80(\mathrm{~m}$, $2 \mathrm{H}), 0.35(\mathrm{~d}, J=0.35 \mathrm{~Hz} 6 \mathrm{H}) .{ }^{19} \mathrm{~F}$ NMR $470 \mathrm{MHz}\left(\mathrm{CDCl}_{3}\right) \delta(\mathrm{ppm})$ : -116.6. ${ }^{13} \mathrm{C}$ NMR $101 \mathrm{MHz}\left(\mathrm{CDCl}_{3}\right) \delta(\mathrm{ppm}): 181.7(\mathrm{~d}, J=2.0 \mathrm{~Hz})$, $162.9(\mathrm{~d}, J=258.4 \mathrm{~Hz}), 144.9(\mathrm{~d}, J=4.7 \mathrm{~Hz}), 127.8(\mathrm{~d}, J=30.8 \mathrm{~Hz})$, $124.4(\mathrm{~d}, J=28.7 \mathrm{~Hz}), 33.4,32,29.3,23.6,22.8,15.7,-2.4$.

2.6.4. Synthesis of 4-Fluoro-2-thiophenecarboxaldehyde (5). Compound $4(0.60 \mathrm{~g}, 1.99 \mathrm{mmol}, 1 \mathrm{eq}$.$) was placed in a round-$ bottom flask with a magnetic stirrer and dissolved in THF $(2 \mathrm{~mL})$. Then, a solution of an aqueous $2 \mathrm{M} \mathrm{HCl}(1.1 \mathrm{~mL}, 1.1$ eq.) was added, and the mixture was cooled at $0{ }^{\circ} \mathrm{C}$. TBAF $3 \mathrm{H}_{2} \mathrm{O}(1 \mathrm{~g}, 3.2 \mathrm{mmol}, 1.6$ eq.) was added, and the reaction mixture was allowed to warm to room temperature and monitored by TLC (eluent: pentane/diethyl ether 90/10). At the end of reaction (typically $1 \mathrm{~h}$ ) the crude mixture (no work-up) was poured on silica gel (eluent: pentane/diethyl ether 90/ $10)$ to afford the titled compound as white solid $(Y=80 \%) .{ }^{1} \mathrm{H}$ NMR $500 \mathrm{MHz}\left(\mathrm{CDCl}_{3}\right) \delta(\mathrm{ppm}): 9.83(\mathrm{~d}, J=1.3 \mathrm{~Hz}, 1 \mathrm{H}), 7.50(\mathrm{~m}, 1 \mathrm{H})$, $7.19(\mathrm{~m}, 1 \mathrm{H}) .{ }^{19} \mathrm{~F}$ NMR $470 \mathrm{MHz}\left(\mathrm{CDCl}_{3}\right) \delta(\mathrm{ppm}):-125.1 .{ }^{13} \mathrm{C}$ NMR $101 \mathrm{MHz}\left(\mathrm{CDCl}_{3}\right) \delta(\mathrm{ppm}): 182.2(\mathrm{~d}, J=2.2 \mathrm{~Hz}), 158.1(\mathrm{~d}, J=$ $262.2 \mathrm{~Hz}), 141.1(\mathrm{~d}, J=4.9 \mathrm{~Hz}), 124.3(\mathrm{~d}, J=24.4 \mathrm{~Hz}), 113.9(\mathrm{~d}, J=$ $20.6 \mathrm{~Hz}$ ). $T_{\mathrm{m}}: 39^{\circ} \mathrm{C}$. Elemental analysis calculated: C, 46.15; H, 2.32; S, 24.64. Found: C, 46.47; H, 2.87; S, 24.65 .

2.6.5. Synthesis of 4-Fluoro-2-thiophenecarbonitrile (6). Compound $5(0.56 \mathrm{~g}, 4.31 \mathrm{mmol}, 1$ eq. $)$ was placed in a round-bottom flask with a magnetic stirrer and then dissolved in NMP $(2 \mathrm{~mL})$. Hydroxylamine hydrochloride (0.36 g, $5.17 \mathrm{mmol}, 1.2$ eq.) was added to the solution, and the mixture was heated at $145{ }^{\circ} \mathrm{C}$ until complete consumption of starting material (typically $3 \mathrm{~h}$ ). At the end of reaction the crude mixture (no work-up) was poured on silica gel (eluent: pentane/diethyl ether 90/10) to afford the desired compound as white solid $(Y=80 \%) .{ }^{1} \mathrm{H}$ NMR $400 \mathrm{MHz}\left(\mathrm{CDCl}_{3}\right) \delta$ (ppm): 7.37 $(\mathrm{dd}, J=1.7,0.8 \mathrm{~Hz}, 1 \mathrm{H}), 7.04(\mathrm{dd}, J=1.7,1.1 \mathrm{~Hz}, 1 \mathrm{H}) .{ }^{19} \mathrm{~F}$ NMR 470 $\mathrm{MHz}\left(\mathrm{CDCl}_{3}\right) \delta(\mathrm{ppm}):-125.9 .{ }^{13} \mathrm{C}$ NMR $126 \mathrm{MHz}\left(\mathrm{CDCl}_{3}\right) \delta$ $(\mathrm{ppm}): 156.9$ (d, $J=261.5 \mathrm{~Hz}), 126.5(\mathrm{~d}, J=27.1 \mathrm{~Hz}), 113.4,111.5$ $(\mathrm{d}, J=20.9 \mathrm{~Hz}), 109.3(\mathrm{~d}, J=10.9 \mathrm{~Hz}) . T_{\mathrm{m}}: 37^{\circ} \mathrm{C}$. Elemental analysis calculated: C, 47.23; H, 1.59; N, 11.02; S, 25.22. Found: C, 48.70; H, 2.24; N, 10.35; S, 24.93.

2.6.6. Synthesis of 3,6-(4-Fluorothiophen-2-yl)pyrrolo[3,4-c]pyrrole-1,4-dione (7). In a two-neck flask equipped with a condenser and an addition funnel, sodium $(0.25 \mathrm{~g}, 10.8 \mathrm{mmol}, 1.2 \mathrm{eq}$.) was added in $15 \mathrm{~mL}$ of 2-methyl-2-butanol, and the mixture was heated at $105^{\circ} \mathrm{C}$ until complete consumption of sodium. Then, 4-fluoro-2-thiophenecarbonitrile (6) (1.15 g, $9.04 \mathrm{mmol}, 1$ eq.) dissolved in $5 \mathrm{~mL}$ of 2 methyl-2-butanol was rapidly added into the mixture, and diisopropyl succinate $(0.83 \mathrm{~mL}, 4.7 \mathrm{mmol}, 0.45$ eq.) was slowly added through the addition funnel. The reaction mixture quickly turned purple. The reaction mixture was stirred overnight at $105{ }^{\circ} \mathrm{C}$. The reaction was cooled at $65^{\circ} \mathrm{C}$ and quenched by an addition of a mixture of methanol $(30 \mathrm{~mL})$ and acetic acid $(10 \mathrm{~mL})$ followed by heating at $90{ }^{\circ} \mathrm{C}$ for 30 $\mathrm{min}$. Then, the reaction mixture was allowed to cool to room temperature, filtered on a Buchner, and washed with methanol to give a purple solid $(Y=75 \%) .{ }^{1} \mathrm{H}$ NMR $400 \mathrm{MHz}$ (DMSO) $\delta(\mathrm{ppm})$ : $11.33(\mathrm{~s}, 2 \mathrm{H}), 8.00(\mathrm{~d}, J=1.8 \mathrm{~Hz}, 2 \mathrm{H}), 7.65(\mathrm{~d}, J=1.5 \mathrm{~Hz}, 2 \mathrm{H}) .{ }^{19} \mathrm{~F}$ NMR $376 \mathrm{MHz}$ (DMSO) $\delta$ (ppm): $-127.1 .{ }^{13} \mathrm{C}$ NMR $101 \mathrm{MHz}$ (DMSO) $\delta(\mathrm{ppm}): 161.4,157(\mathrm{~d}, J=256.5 \mathrm{~Hz}), 136.2,129.2(\mathrm{~d}, J=$ $9.8 \mathrm{~Hz}), 119.3(\mathrm{~d}, J=27.5 \mathrm{~Hz}), 111.4(\mathrm{~d}, J=21.2 \mathrm{~Hz}), 109.4$.

2.6.7. Synthesis of 3,6-(4-Fluorothiophen-2-yl)-2,5-bis(decyl)pyrrolo[3,4-c]pyrrole-1,4-dione (M5). In a two-neck flask equipped with a condenser and an addition funnel, compound 7 (0.51 g, 1.51 mmol, 1 eq.) and anhydrous potassium carbonate $(1 \mathrm{~g}, 4.55 \mathrm{mmol}, 3$ eq.) were stirred in $8 \mathrm{~mL}$ of anhydrous DMF. The mixture was heated at $85{ }^{\circ} \mathrm{C}$ for $30 \mathrm{~min}$, and then 1-bromodecane $(0.632 \mathrm{~g}, 4.55 \mathrm{mmol}, 3$ eq.) was slowly added. The reaction mixture was stirred overnight at $85^{\circ} \mathrm{C}$. After cooling to room temperature, the reaction was quenched with a saturated solution of $\mathrm{NH}_{4} \mathrm{Cl}$ and extracted three times with diethyl ether. The combined organic phases were washed with water and brine, dried over $\mathrm{MgSO}_{4}$, and concentrated under vacuum. Purification was achieved by column chromatography (silica gel; eluent: chloroform/hexanes 65/35) affording the desired compound as a purple solid $(Y=40 \%) .{ }^{1} \mathrm{H}$ NMR $500 \mathrm{MHz}\left(\mathrm{CDCl}_{3}\right) \delta(\mathrm{ppm})$ : $8.70(\mathrm{~d}, J=1.7 \mathrm{~Hz}, 2 \mathrm{H}), 7.04(\mathrm{dd}, J=1.6,0.5 \mathrm{~Hz}, 2 \mathrm{H}), 4.05-4.01(\mathrm{~m}$, $4 \mathrm{H}), 1.76-1.70(\mathrm{~m}, 4 \mathrm{H}), 1.43-1.25(\mathrm{~m}, 28 \mathrm{H}), 0.87(\mathrm{t}, J=7 \mathrm{~Hz}, 6 \mathrm{H})$. ${ }^{19} \mathrm{~F}$ NMR $470 \mathrm{MHz}\left(\mathrm{CDCl}_{3}\right) \delta(\mathrm{ppm}):-126 .{ }^{13} \mathrm{C}$ NMR $101 \mathrm{MHz}$ $\left(\mathrm{CDCl}_{3}\right) \delta(\mathrm{ppm}): 161.1,158.7(\mathrm{~d}, J=260.3 \mathrm{~Hz}), 139.5(\mathrm{~d}, J=3.2$ $\mathrm{Hz}), 128.2(\mathrm{~d}, J=9.3 \mathrm{~Hz}), 123.9(\mathrm{~d}, J=27.6 \mathrm{~Hz}), 109.3(\mathrm{~d}, J=21.4$ $\mathrm{Hz}), 108.3,42.4,32,30.1,29.6,29.4,29.3,27,22.8,14.3$.

2.6.8. Synthesis of 3,6-(4-Fluorothiophen-2-yl)-2,5-bis(dodecyl)pyrrolo[3,4-c]pyrrole-1,4-dione (M6). M6 was synthesized and purified according to the procedure described for M5 using 1bromododecane instead of 1-bromodecane affording the desired compound as a purple solid $(Y=43 \%) .{ }^{1} \mathrm{H}$ NMR $500 \mathrm{MHz}\left(\mathrm{CDCl}_{3}\right) \delta$ (ppm): 8.69 (d, $J=1.7 \mathrm{~Hz}, 2 \mathrm{H}), 7.04(\mathrm{dd}, J=1.6,0.5 \mathrm{~Hz}, 2 \mathrm{H}), 4.05-$ $4.01(\mathrm{~m}, 4 \mathrm{H}), 1.77-1.69(\mathrm{~m}, 4 \mathrm{H}), 1.40-1.25(\mathrm{~m}, 36 \mathrm{H}), 0.87(\mathrm{t}, J=7$ $\mathrm{Hz}, 6 \mathrm{H}) .{ }^{19} \mathrm{~F}$ NMR $376 \mathrm{MHz}\left(\mathrm{CDCl}_{3}\right) \delta(\mathrm{ppm}):-126 .{ }^{13} \mathrm{C}$ NMR 101 $\mathrm{MHz}\left(\mathrm{CDCl}_{3}\right) \delta(\mathrm{ppm}): 161.1,158.7(\mathrm{~d}, J=260.2 \mathrm{~Hz}), 139.5(\mathrm{~d}, J=$ $3.0 \mathrm{~Hz}), 128.2(\mathrm{~d}, J=9.4 \mathrm{~Hz}), 123.9(\mathrm{~d}, J=27.5 \mathrm{~Hz}), 109.3(\mathrm{~d}, J=$ $21.5 \mathrm{~Hz}), 108.3,42.4,32.1,30.1,29.8,29.7,29.6,29.5,29.4,27,22.8$, 14.3.

2.7. Synthesis of Polymers by Direct Heteroarylation Polymerization (DHAP). 2.7.1. Synthesis of P2. M6 (0.082 mmol, 1 eq.), M4 (0.082 mmol, 1 eq.), trans-bis(acetato)bis[o-(di-otolylphosphino)benzyl]dipalladium(II) (2\% mol), tris(2-methoxyphenyl)phosphine ( $8 \% \mathrm{~mol}$ ), $\mathrm{Cs}_{2} \mathrm{CO}_{3}$ (3 eq.), and pivalic acid (1 eq. ) were put in a microwave vial with a magnetic stirring bar. The vial was sealed with a cap and then purged with nitrogen to remove the oxygen $(3 \times)$. Degassed and anhydrous toluene was added $(C=0.2$ $\left.\mathrm{mol} \mathrm{L}{ }^{-1}, 0.4 \mathrm{~mL}\right)$, and the microwave vial was heated at $120^{\circ} \mathrm{C}$ using a slow temperature ramp. After heating for $16 \mathrm{~h}, 0.2 \mathrm{~mL}$ of degassed and anhydrous toluene was added. Four hours later the reaction was cooled to $65^{\circ} \mathrm{C}$, and then $1 \mathrm{~mL}$ of TCB was added. The mixture was poured in methanol/acidified water $(10 \% \mathrm{HCl} ; 9: 1$ ratio), and the solid was recovered by filtration using a $0.45 \mu \mathrm{m}$ nylon filter. The polymer was washed using a Soxhlet apparatus with acetone, hexanes, dichloromethane, and then chloroform. The chloroform fraction was reduced to $5-10 \mathrm{~mL}$ and then poured in methanol. The polymer was recovered by filtration over a $0.45 \mu \mathrm{m}$ nylon filter and dry under vacuum $(Y=73 \%)$.

2.7.2. Synthesis of P3. M1 (0.167 mmol, 1 eq.), M2 ( $0.167 \mathrm{mmol}$, 1 eq.), $\mathrm{Pd}_{2} \mathrm{dba}_{3}$ (4\% mol), tris(2-cycloheptyloxyphenyl)phosphine (BuraPhos) (20\% mol), $\mathrm{K}_{2} \mathrm{CO}_{3}$ (40 eq.), and pivalic acid (1 eq.) were put in a microwave vial with a magnetic stirring bar. The vial was sealed with a cap and then purged with nitrogen to remove the oxygen $(3 \times)$. Degassed and anhydrous THF was added $\left(C=0.1 \mathrm{~mol} \mathrm{~L}^{-1}, 1.7\right.$ $\mathrm{mL}$ ), and the reaction was heated with an oil bath preheated at $120^{\circ} \mathrm{C}$ (reaction under pressure) until gelation of the reaction mixture $(16 \mathrm{~h})$. The reaction was cooled to $65{ }^{\circ} \mathrm{C}$, and then $1 \mathrm{~mL}$ of TCB was added. The mixture was poured in methanol/acidified water $(10 \% \mathrm{HCl} ; 9: 1$ ratio), and the solid was recovered by filtration using a $0.45 \mu \mathrm{m}$ nylon filter. The polymer was washed using a Soxhlet apparatus with acetone, hexanes, and then chloroform. The chloroform fraction was reduced to $5-10 \mathrm{~mL}$ and then poured in methanol. The polymer was recovered by filtration over a $0.45 \mu \mathrm{m}$ nylon filter and dry under vacuum $(Y=$ 
Scheme 2. Synthetic Pathway for Synthesis of 4-Fluoro-2-thiophenecarbonitrile
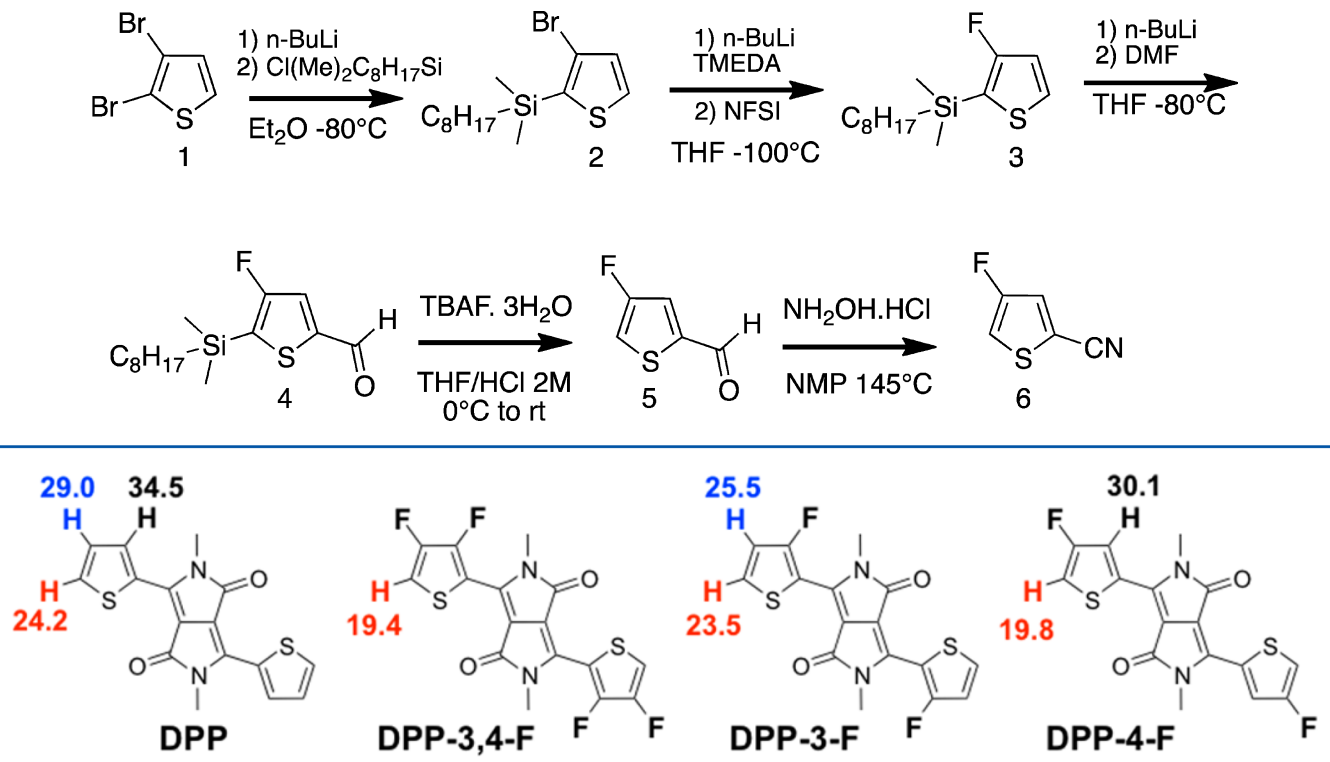

Figure 1. Computationally calculated Gibbs free energy of the CMD transition state associated with the transition state for the $\mathrm{C}-\mathrm{H}$ bond cleavage at the $\alpha, \beta$, and $\gamma$ positions.

91\%). ${ }^{1} \mathrm{H}$ NMR $500 \mathrm{MHz}\left(\mathrm{TCE}\right.$ at $\left.100{ }^{\circ} \mathrm{C}\right) \delta(\mathrm{ppm}): 9.03,8.20,7.87$, $7.65,4.72,4.24,2.41,2.14,1.94,1.58,1.51,1.39,1.25,0.97,0.88$.

2.7.3. Synthesis of P4. M1 (0.131 mmol, 1 eq.), M5 ( $0.131 \mathrm{mmol}$, 1 eq.), $\mathrm{Pd}(\mathrm{OAc})_{2}$ (4\% mol), tris(2-methoxyphenyl)phosphine (16\% $\mathrm{mol}), \mathrm{Cs}_{2} \mathrm{CO}_{3}$ (3 eq.), and pivalic acid (1 eq.) were put in a microwave vial with a magnetic stirring bar. The vial was sealed with a cap and then purged with nitrogen to remove the oxygen $(3 \times)$. Degassed and anhydrous THF was added $\left(C=0.1 \mathrm{~mol} \mathrm{~L}^{-1}, 1.3 \mathrm{~mL}\right)$, and the reaction was heated with an oil bath preheated at $100{ }^{\circ} \mathrm{C}$ (reaction under pressure) until gelation of the reaction mixture $(15 \mathrm{~min})$. The reaction was cooled to $65^{\circ} \mathrm{C}$, and then $1 \mathrm{~mL}$ of TCB was added. The mixture was poured in methanol/acidified water $(10 \% \mathrm{HCl})(9: 1)$, and the solid was recovered by filtration using a $0.45 \mu \mathrm{m}$ nylon filter. The polymer was washed using a Soxhlet apparatus with acetone, hexanes, and then chlorobenzene. The chlorobenzene fraction was reduced to $5-10 \mathrm{~mL}$ and then poured in methanol. The polymer was recovered by filtration over a $0.45 \mu \mathrm{m}$ nylon filter and dry under vacuum $(Y=$ $80 \%)$.

2.7.4. Synthesis of P5. M1 (0.139 mmol, 1 eq.), M5 ( $0.139 \mathrm{mmol}$, 1 eq.), $\mathrm{Pd}(\mathrm{OAc})_{2}$ (4\% mol), tris(2-cycloheptyloxyphenyl)phosphine (BuraPhos) (16\% mol), $\mathrm{Cs}_{2} \mathrm{CO}_{3}$ (3 eq.), and pivalic acid (1 eq.) were put in a microwave vial with a magnetic stirring bar. The vial was sealed with a cap and then purged with nitrogen to remove the oxygen (3X). Degassed and anhydrous THF was added $\left(C=0.1 \mathrm{~mol} \mathrm{~L}^{-1}, 1.4\right.$ $\mathrm{mL})$, and the reaction was heated with an oil bath preheated at $100{ }^{\circ} \mathrm{C}$ (reaction under pressure) until gelation of the reaction mixture (30 min). The reaction was cooled to $65^{\circ} \mathrm{C}$, and then $1 \mathrm{~mL}$ of TCB was added. The mixture was poured in methanol/acidified water $(10 \%$ $\mathrm{HCl})(9: 1)$, and the solid was recovered by filtration using a $0.45 \mu \mathrm{m}$ nylon filter. The polymer was washed using a Soxhlet apparatus with acetone, hexanes, and then chlorobenzene. The chlorobenzene fraction was reduced to $5-10 \mathrm{~mL}$ and then poured in methanol. The polymer was recovered by filtration over a $0.45 \mu \mathrm{m}$ nylon filter and dry under vacuum $(Y=85 \%)$.

\section{RESULTS AND DISCUSSION}

\subsection{Justification of the Fluorination Position on the} Thiophene Moiety. As recently shown by Jiang et al., despite the similar size of fluorine and hydrogen atoms, the fluorination position on the phenyl group led to undesired torsion of the fluorinated diphenyl-DPP core. $^{64}$ While alkylated diphenyl-
DPP is known to be twisted and alkylated dithienyl-DPP is coplanar, one can think that the fluorination position on the thiophene ring would also affect the coplanarity of the resulting fluorinated dithenyl-DPP which can be detrimental for the electro-optical properties. We then performed conformation analyses based on density functional theory to gauge the effect of both the amount and the position of fluorine atoms on the molecular structure of fDT-DPP (see Table S1 in Supporting Information). The theoretical calculations revealed that when a fluorine atom is pointing toward the DPP core, the coplanarity is lost (DPP-3-F). On the other hand, the coplanarity of the fluorinated dithienyl-DPP is not affected when the fluorine atom is pointing away from the DPP core (DPP-4-F). Owing to these theoretical data, one can think that the synthesis of 4fluoro-2-thiophenecarbonitrile (compound 6, Scheme 2) would lead to coplanar fluorinated dithienyl-DPP moiety.

Recently, we have shown that theoretical calculations can also be used to rationalize and predict regioselectivity of the direct heteroarylation polymerization..$^{70,71} \mathrm{We}$ performed a similar study using non-fluorinated DT-DPP moiety as reference to probe the effect of both different patterns on the activation energy (Gibbs free energy) of the $\mathrm{C}-\mathrm{H}$ bond of the thiophene moiety in a catalytic direct heteroarylation polymerization. As shown in Figure 1, for DPP, a difference in the activation energy $\left(\Delta E_{\mathrm{a}}\right)$ between $\mathrm{H}_{\alpha}\left(24.2 \mathrm{kcal} \mathrm{mol}^{-1}\right)$ and $\mathrm{H}_{\beta}$ $\left(29.0 \mathrm{kcal} \mathrm{mol}^{-1}\right)$ of $4.8 \mathrm{kcal} \mathrm{mol}^{-1}$ was calculated. Using Arrhenius's law, it is possible to tentatively estimate a selectivity ratio of the $\alpha$-position at $120{ }^{\circ} \mathrm{C}$ (the temperature of polymerization). For this system, a ratio of about 450/1 favoring $\mathrm{H}_{\alpha}$ can indeed be calculated for the DPP unit. Moreover, a difference in the activation energy $\left(\Delta E_{\mathrm{a}}\right)$ between $\mathrm{H}_{\alpha}$ and $\mathrm{H} \gamma$ for DPP is found to be at $10.3 \mathrm{kcal} \mathrm{mol}^{-1}(24.2 \mathrm{kcal}$ $\mathrm{mol}^{-1}$ vs $34.5 \mathrm{kcal} \mathrm{mol}^{-1}$ ), giving a higher selectivity in favor of $\mathrm{H}_{\alpha}$ (about 530000/1). For DPP-3,4-F, only one $\mathrm{C}-\mathrm{H}$ bond is available for the concerted metalation-deprotonation (CMD) step in DHAP with an activation energy calculated at $19.4 \mathrm{kcal}$ $\mathrm{mol}^{-1}$. This lower activation energy value, compared to the activation energy of $\mathrm{H}_{\alpha}$ of DPP $\left(24.2 \mathrm{kcal} \mathrm{mol}^{-1}\right)$, shows the 
Scheme 3. Synthetic Pathway for Synthesis of Monomers M5 and M6
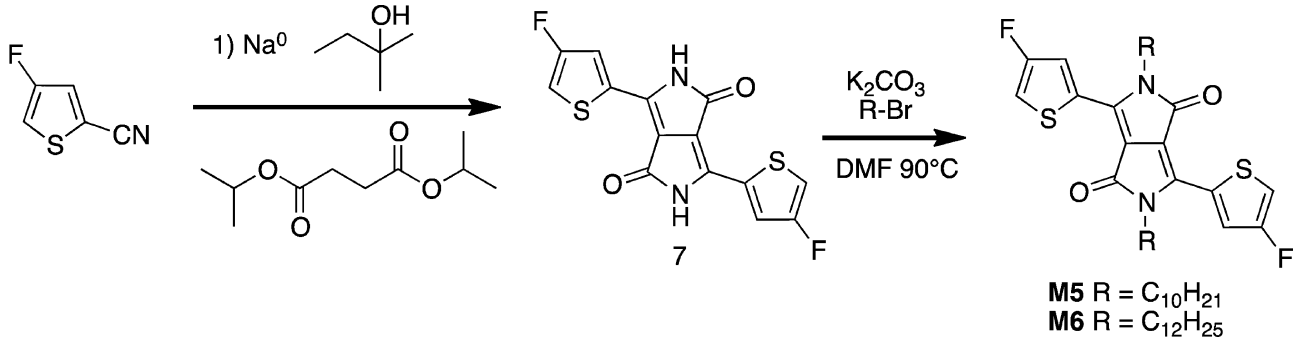

Table 1. Properties of Polymers

\begin{tabular}{|c|c|c|c|c|c|c|c|c|c|c|}
\hline \multirow[b]{2}{*}{ entry } & \multirow[b]{2}{*}{$\bar{M}_{\mathrm{n}}\left(\mathrm{kg} \mathrm{mol}^{-1}\right)$} & \multirow[b]{2}{*}{$Đ$} & \multirow[b]{2}{*}{ yield (\%) } & \multirow[b]{2}{*}{ reaction time } & \multirow[b]{2}{*}{ HOMO $(\mathrm{eV})$} & \multirow[b]{2}{*}{ LUMO (eV) } & \multicolumn{2}{|c|}{$\lambda_{\max , \mathrm{abs}}(\mathrm{nm})$} & \multirow[b]{2}{*}{$E_{\mathrm{g}}^{\mathrm{opt}}(\mathrm{eV})$} & \multirow[b]{2}{*}{ TGA $\left({ }^{\circ} \mathrm{C}\right)$} \\
\hline & & & & & & & solution & thin film & & \\
\hline $\mathbf{P 1} 1^{66}$ & 16 & 2.4 & 93 & $20 \mathrm{~h}$ & -5.45 & -4.14 & $820 / 920$ & $846 / 927$ & 1.17 & n.a \\
\hline P2 & 22 & 3.0 & 73 & $20 \mathrm{~h}$ & -5.71 & -4.04 & $887 / 962$ & $859 / 967$ & 1.15 & 430 \\
\hline P3 & 44 & 3.0 & 91 & $16 \mathrm{~h}$ & -5.46 & -3.82 & $622 / 655$ & $630 / 689$ & 1.68 & 420 \\
\hline P4 & 51 & 3.7 & 90 & $15 \min$ & -5.68 & -3.97 & $639 / 702$ & $639 / 702$ & 1.65 & 420 \\
\hline P5 & 125 & 3.0 & 85 & $30 \mathrm{~min}$ & -5.68 & -3.97 & $639 / 702$ & $639 / 702$ & 1.65 & 420 \\
\hline
\end{tabular}

effect of electron-withdrawing fluorine atom on the adjacent $\mathrm{C}-\mathrm{H}$ bond. For DPP-3-F a difference in the activation energy $\left(\Delta E_{\mathrm{a}}\right)$ between $\mathrm{H}_{\alpha}\left(23.5 \mathrm{kcal} \mathrm{mol}^{-1}\right)$ and $\mathrm{H}_{\beta}\left(25.5 \mathrm{kcal} \mathrm{mol}^{-1}\right)$ is only of $2.0 \mathrm{kcal} \mathrm{mol}^{-1}$. Here, theoretical calculations show that the electron-withdrawing fluorine atom strongly modifies the activation energy of $\mathrm{C}-\mathrm{H}_{\beta}$ bond $\left(25.5 \mathrm{kcal} \mathrm{mol}^{-1}\right)$ and has a small influence on the $\mathrm{C}-\mathrm{H}_{\alpha}\left(23.5 \mathrm{kcal} \mathrm{mol}^{-1}\right)$. Indeed, while the activation energy of $\mathrm{H}_{\alpha}$ is $23.5 \mathrm{kcal} \mathrm{mol}^{-1}$ for DPP-3-F, the activation energy of $\mathrm{H}_{\beta}$ is lowered at $25.5 \mathrm{kcal} \mathrm{mol}^{-1}$ compared to $29 \mathrm{kcal} \mathrm{mol}^{-1}$ for DPP which leads to lower selectivity in favor of $\mathrm{H}_{\alpha}(15 / 1)$ compared to $450 / 1$ for DPP. Finally, for DPP-4-F, an activation energy of $19.8 \mathrm{kcal} \mathrm{mol}^{-1}$ for $\mathrm{H}_{\alpha}$ and $30.1 \mathrm{kcal} \mathrm{mol}^{-1}$ for $\mathrm{H}_{\gamma}$ were calculated. In this case, the position of the fluorine atom on the flanking thiophene influences both $\mathrm{H}_{\alpha}$ and $\mathrm{H}_{\gamma}$. Indeed, when compared to DPP, activation energies are lowered $\left(\mathrm{H}_{\alpha} 19.8\right.$ vs $24.2 \mathrm{kcal} \mathrm{mol}^{-1} ; \mathrm{H}_{\gamma}=30.1 \mathrm{vs} 34.5 \mathrm{kcal}$ $\left.\mathrm{mol}^{-1}\right)$. Although the activation energy of $\mathrm{H} \gamma$ is decreased by $4.4 \mathrm{kcal} \mathrm{mol}^{-1}$ compared to DPP, a selectivity of about $500000 /$ 1 in favor of $\mathrm{H}_{\alpha}$ over $\mathrm{H}_{\gamma}$ was calculated meaning that the polymerization reaction will likely proceed at the $\alpha$-position and lead to well-defined copolymer. By combining the conformational analyses and the activation energy of each C$\mathrm{H}$ bond, DPP-4-F derivatives would be the most useful fluorinated DPP core to obtain well-defined and coplanar conjugated polymer by DHAP.

3.2. Synthesis of Monomers. On the basis of our previous work on fluorinated poly(3-alkylthiophene)s and fluorinated dithiophene-benzothiadiazole, ${ }^{71,72}$ we synthesized 3-bromo-2(dimethyloctylsilyl)thiophene (2) from lithiation of 2,3dibromothiophene $(\mathbf{1})$ in diethyl ether $\left(\right.$ at $\left.-80{ }^{\circ} \mathrm{C}\right)$ with $n$ BuLi followed by treatment with $n$-octyldimethylchlorosilane (Scheme 2). 3-Bromo-2-(dimethyloctylsilyl)thiophene was purified by vacuum distillation and obtained in $85 \%$ yield. Subsequent lithiation of 2 at $-100{ }^{\circ} \mathrm{C}$ in THF followed by a fast addition of NFSI via cannula provided 3-fluoro-2(dimethyloctylsilyl)thiophene (3) in 65\% yield. Unlike other fluorothiophene derivatives reported in the literature, which are purified using reverse phase chromatography, ${ }^{71-73}$ compound 3 was purified using silica gel. However, our synthetic procedure led to 3-fluorothiophene derivatives with traces of dehalogenated compound (2-(dimethyloctylsilyl)thiophene) easily removed by normal phase chromatography. It is worth noting that freshly recrystallized NFSI, control of the reaction temperature $\left(-100{ }^{\circ} \mathrm{C}\right)$ and the use of TMEDA are mandatory to obtain 3 in a good yield. Lithiation of 3 with $n$-BuLi followed by quenching of the reaction with $N, N$-dimethylformamide led to 4-fluoro-5-(dimethyloctylsilyl)-2-thiophenecarboxaldehyde (4) in $85 \%$ yield. Compound 4 was treated with an excess of tetrabutylammonium fluoride trihydrate $\left(\mathrm{TBAF} \cdot 3 \mathrm{H}_{2} \mathrm{O}\right)$ in a mixture of $\mathrm{THF} / \mathrm{HCl}$ at room temperature to afford pure 4fluoro-2-thiophenecarboxaldehyde (5) in $85 \%$ yield. Treatment of 5 with hydroxylamine hydrochloride in NMP at $145{ }^{\circ} \mathrm{C}$ followed by purification by column chromatography led to 4 fluoro-2-thiophenecarbonitrile (6) without any traces of 2thiophenecarbonitrile, a byproduct observed by El Kassmi et al. $^{74}$ The absence of traces of 2-thiophenecarbonitrile is of paramount of importance for the next step that leads to the diketopyrrolopyrrole core with fluorinated flanking thiophene (fDT-DPP) (Scheme 3). Then, 3,6-(4-fluorothiophen-2-yl)pyrrolo[3,4-c]pyrrole-1,4-dione (7) was synthesized in one step by consecutive condensation of succinate ester with $(6)$ in the presence of sodium alkoxide in $75 \%$. In addition to the modification of the electronic properties of the DPP core, the fluorine atom installed on the 4-position on the flanking thiophene prevents $\beta$-branching and activates the $\mathrm{C}-\mathrm{H}$ bond in $\alpha$-position for DHAP. Alkylation with either 1-bromodecane or 1-bromododecane led to M5 and M6 in 40\% and 43\% yields, respectively.

3.3. Synthesis and Characterization of Polymers. Fluorinated dithienyl-DPP-based copolymers were prepared by direct (hetero)arylation polymerization following guidelines found in our previous reports investigating reactivity ${ }^{75}$ and selectivity $^{70}$ (Scheme 1). Non-fluorinated P1 was already reported in the literature. ${ }^{66}$ In all cases, the polymerization reaction was stopped upon gelation of the reaction mixture. After precipitation in methanol, the polymers were purified by successive Soxhlet extractions. We found that the fluorine atom installed on the flanking thiophenes of the DPP moiety led to shorter polymerization times and higher molecular weights. As shown in Table 1, all the fluorinated copolymers have higher molecular weights compared to their non-fluorinated analogues. As an example, P3 (Scheme 1) exhibits a number-average 


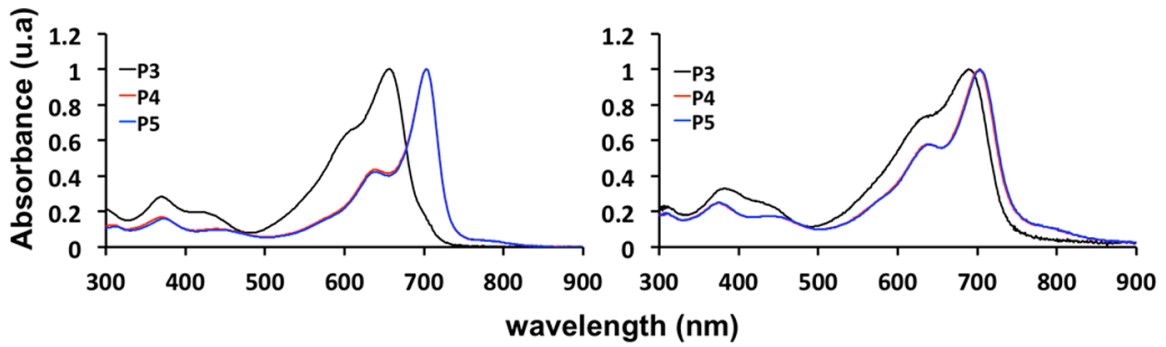

Figure 2. UV-vis absorption spectra of P3-P5 in solution in $\mathrm{CHCl}_{3}$ (left) and in the solid state (right).

molecular weight of $44 \mathrm{~kg} \mathrm{~mol}^{-1}$ after $16 \mathrm{~h}$ of reaction, whereas, using the same polymerization conditions, $\mathbf{P 4}$ reached a number-average molecular weight of $51 \mathrm{~kg} \mathrm{~mol}^{-1}$ after only 15 min of reaction. Recently, we have shown that the use of bulky phosphine-based ligand can increase the selectivity of the DHAP while decreasing the unwanted homocoupling. ${ }^{70}$ P5 was synthesized using tris(2-cycloheptyloxyphenyl)phosphine (BuraPhos) instead of tris(2-methoxyphenyl)phosphine, and a number-average molecular weight up to $125 \mathrm{~kg} \mathrm{~mol}^{-1}$ was obtained after $30 \mathrm{~min}$. This shorter polymerization time observed for P4 and P5 compared to P3 (see Table 1) can be attributed to the strong electron-withdrawing effect of the fluorine atom on the $\alpha \mathrm{C}-\mathrm{H}$ bond. The results obtained are in good agreement with the DFT calculations. Fluorinated dithienyl-DPP (fDT-DPP) pseudo-homopolymer (P2) was synthesized for OFETs applications while fluorinated-DPP/ carbazole copolymers (P3-P5) were synthesized for PSCs applications.

Thermal properties were evaluated by thermal gravimetric analysis (TGA) and differential scanning calorimetry (DSC). All polymers exhibit good thermal stability with $5 \%$ weight loss at temperature higher than $400{ }^{\circ} \mathrm{C}$ (see Table 1) while DSC traces did not revealed any thermal transition. NMR spectroscopy was useless to identify any $\beta$-branching or homocoupling within the conjugated backbone due to broad and featureless signals. Although a well-resolved ${ }^{1} \mathrm{H}$ NMR spectrum was obtained for P3 (TCE at $100{ }^{\circ} \mathrm{C}$, see Supporting Information), the fluorinated analogues $\mathbf{P 4}$ and P5 exhibit strong aggregation and were barely soluble even in TCE at $100{ }^{\circ} \mathrm{C}$.

As reported in the literature, the solid-state UV-vis-NIR absorption spectrum of $\mathbf{P} \mathbf{1}$ shows a maximum of absorption at $927 \mathrm{~nm}$ with a shoulder at $846 \mathrm{~nm}$ and an optical bandgap of $1.17 \mathrm{eV} .^{66}$ For P2 (fluorinated analogue of P1), bathochromic shifts were observed for each the maximum of absorption (40 $\mathrm{nm}$ ) and the shoulder $(13 \mathrm{~nm}$ ) (see Figure $\mathrm{S} 40$ in the Supporting Information). The optical bandgap taken from then onset of the absorption spectrum is $1.15 \mathrm{eV}$. The effect of the fluorine atom on the optical properties was also observed for P3-P5 polymers in dilute chloroform solution (Figure 2). Indeed, a strong bathochromic shift $(47 \mathrm{~nm})$ of the maximum of absorption was observed for P4 and P5 (702 nm) compared to that of P3 $(655 \mathrm{~nm})$. However, in the solid state, a bathochromic shift of $34 \mathrm{~nm}$ was observed for P3 while no such behavior was found for P4 and P5, suggesting strong aggregation in solution. Cyclic voltammetry analyses were performed to gauge the influence of the fluorine atom on the electronic properties (see Figures S1 and S2). We observed a decrease of both HOMO (highest occupied molecular orbital) and LUMO (lowest unoccupied molecular orbital) energy levels (see Table 1). ${ }^{28}$ For example, the HOMO of P4 and P5 was stabilized by $0.22 \mathrm{eV}$ compared to $\mathbf{P} 3$ while the LUMO decreased from $-3.82 \mathrm{eV}(\mathbf{P} 3)$ to $-3.97 \mathrm{eV}$ (P4, P5). X-ray diffraction analyses (powder) were also performed (see Figures S37-S39). Typical $d$-spacing and lamellar distances for conjugated polymers were found for each fDT-DPP copolymer.

3.4. OFETs. To evaluate the semiconducting properties of P2, we prepared bottom-gate/bottom-contact (BGBC) OFETs devices. All spin-coating processes were carried out under nitrogen, and the active channel layers were annealed at different temperatures for $20 \mathrm{~min}$ under nitrogen prior to measurements. OFET characteristics of the devices were measured under nitrogen conditions, and the field-effect mobility was extracted from the saturation regimes. P2 displayed ambipolar properties, and the device performance data are outlined in Table 2 and compared with previously

Table 2. OFETs Performances

\begin{tabular}{|c|c|c|c|c|}
\hline & \multicolumn{2}{|c|}{ p-channel } & \multicolumn{2}{|c|}{ n-channel } \\
\hline & $\mu_{\mathrm{h}}^{a}\left(\mathrm{~cm}^{2} \mathrm{~V}^{-1} \mathrm{~s}^{-1}\right)$ & $I_{\text {on }} / I_{\text {off }}^{b}$ & $\mu_{\mathrm{e}}^{a}\left(\mathrm{~cm}^{2} \mathrm{~V}^{-1} \mathrm{~s}^{-1}\right)$ & $I_{\text {on }} / I_{\text {off }}^{b}$ \\
\hline $\mathbf{P 1}^{66}$ & $0.22^{c}$ & $10^{3}$ & $0.19^{d}$ & n.a \\
\hline P2 & $0.80^{c}(0.73)$ & $10^{3}$ & $0.51^{c}(0.50)$ & $10^{2}$ \\
\hline
\end{tabular}

${ }^{a}$ Maximum mobilities measured under nitrogen in saturated regime. The average values are in parentheses. ${ }^{b}$ Current on/off ratio. ${ }^{c}$ Bottom gate bottom contact configuration (BGBC), where the $\mathbf{P 2}$ films were annealed at $100{ }^{\circ} \mathrm{C}$ for $20 \mathrm{~min}$ in nitrogen. ${ }^{d}$ Top gate bottom contact configuration (TGBC).

reported P1. ${ }^{66}$ Figure 3 shows the transfer and output characteristics of the BGBC devices based on P2. The output characteristics follow a typical trend exhibited by ambipolar devices where a superlinear increase in current is observed at low $V_{\mathrm{GS}}$ and high $V_{\mathrm{DS}}$, which is due to the injection of the opposite charge carrier, and superposed standard saturation behavior with increasing $V_{\mathrm{GS}}$ for the dominant charge carrier. From the transfer characteristics, we observe $\mathrm{V}$-shaped $I_{\mathrm{DS}}$ patterns. As presented in Table 2, $\mathbf{P 2}$ exhibited high mobilities with the maxima $\mu_{\mathrm{h}}$ and $\mu_{\mathrm{e}}$ of $0.80 \mathrm{~cm}^{2} \mathrm{~V}^{-1} \mathrm{~s}^{-1}$ and $0.51 \mathrm{~cm}^{2}$ $\mathrm{V}^{-1} \mathrm{~s}^{-1}$, respectively. The hole and electron mobilities are quite balanced with an average $\mu_{\mathrm{e}} / \mu_{\mathrm{h}}$ of 0.68 . In all cases, forward and backward scans in the transfer and output curves exhibited pronounced hysteresis of $I_{\mathrm{DS}}$, which is frequently observed for OFETs due to trapping of the charge carriers in the gate dielectrics, at the interface of the active channel layer and dielectric, or in the active channel layer. ${ }^{76-78}$

3.5. PSCs. As mentioned earlier, DPP-carbazole copolymers were investigated as electron donor in bulk heterojunction solar cells. Out-of-plane hole mobilities have been measured by using hole-only space-charge limited current (SCLC) devices (see Figure S41). For pure polymer films, the hole mobilities are found to be slightly higher in fluorinated polymers $((1.9 \pm 0.3)$ $\times 10^{-4}$ and $(2.3 \pm 0.4) \times 10^{-4} \mathrm{~cm}^{2} \mathrm{~V}^{-1} \mathrm{~s}^{-1}$ for P4 and P5, 

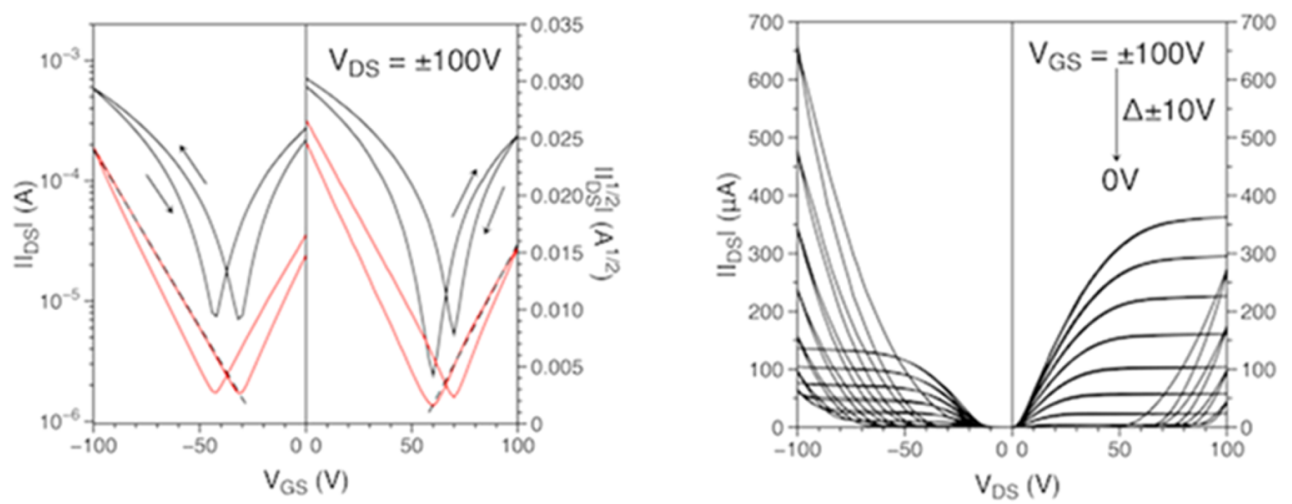

Figure 3. Transfer (left) and output (right) characteristics of a typical BGBC OFET device with $\mathbf{P 2}$ as the channel semiconductor, which show ambipolar behavior. The $\mathbf{P 2}$ film was annealed at $100{ }^{\circ} \mathrm{C}$ for $20 \mathrm{~min}$ in nitrogen.

respectively) compared to the non-fluorinated P3 polymer $\left((5.0 \pm 1.0) \times 10^{-5} \mathrm{~cm}^{2} \mathrm{~V}^{-1} \mathrm{~s}^{-1}\right)$. These moderate mobility values are sufficient to consider these polymers, and especially the fluorinated derivatives, as interesting electron-donor candidates in $\mathrm{BHJ}$ solar cells. P3-P5 polymers have been characterized in blends with [6,6]-phenyl $\mathrm{C}_{71}$-butyric acid methyl ester $\left(\mathrm{PC}_{70} \mathrm{BM}\right)$ as electron-acceptor using an inverted device structure. The current density-voltage $(J-V)$ characteristics of the solar cells measured under simulated AM 1.5G irradiation (with intensity of $100 \mathrm{~mW} \mathrm{~cm} \mathrm{~cm}^{-2}$ ) are shown in Figure 4. The PSC parameters are summarized in Table 3. For

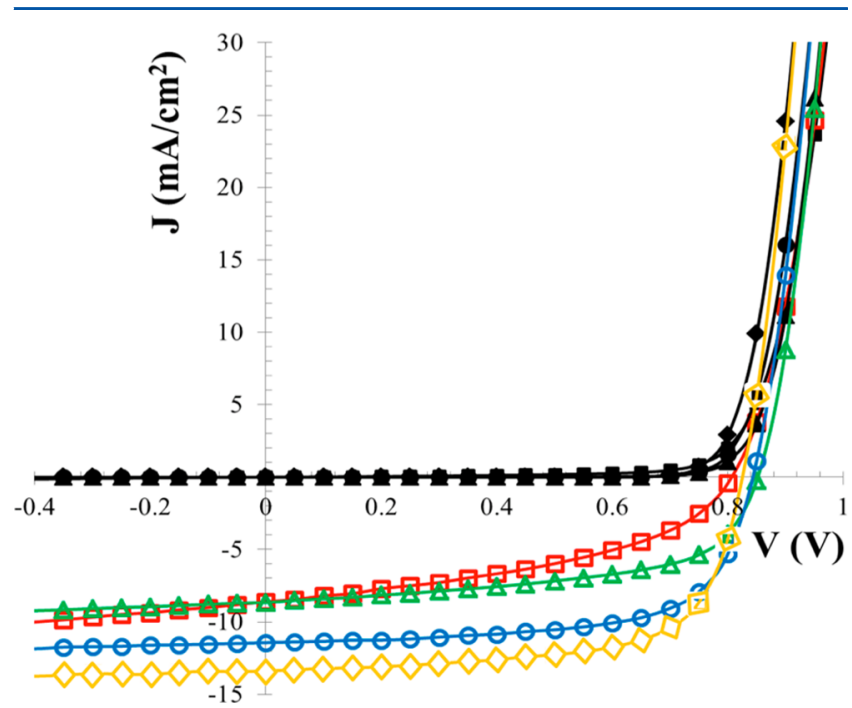

Figure 4. $J-V$ characteristics measured in the dark (closed symbols) and under standard (AM1.5G $100 \mathrm{~mW} / \mathrm{cm}^{2}$ ) conditions (open symbols) for P3 (squares), P4 (triangles), P5 with DIO (circles), and P5 with DPE (diamonds).

Table 3. Best Photovoltaic Parameters Measured with Different Polymers ${ }^{a}$

$\begin{array}{cccccc}\text { polymer } & \text { additive } & V_{\mathrm{oc}}(\mathrm{mV}) & J_{\mathrm{sc}}\left(\mathrm{mA} / \mathrm{cm}^{2}\right) & \mathrm{FF}(\%) & \text { PCE (\%) } \\ \text { P3 } & \text { DIO } & 807 & 8.63 & 44.1 & 3.07(3.0) \\ \text { P4 } & \text { DIO } & 854 & 8.57 & 57.7 & 4.23(4.1) \\ \text { P5 } & \text { DIO } & 845 & 11.4 & 65.9 & 6.37(6.2) \\ \text { P5 } & \text { DPE } & 828 & 13.6 & 65.8 & 7.47(7.3)\end{array}$

${ }^{a}$ Values in parentheses are average PCE values. both fluorinated polymers (P4 and P5), using DIO as additive, the open-circuit voltage $\left(V_{o c}\right)$ is slightly higher (by roughly 50 $\mathrm{mV}$ ) than for the non-fluorinated polymers, in good agreement with the experimental HOMO energy levels reported in Table 1. The PCEs for fluorinated polymers are higher than those obtained for the non-fluorinated analogue. The best results are obtained for the high molecular weight polymer P5, with significantly larger short-circuit current densities $\left(J_{\text {sc }}\right)$ and fill factors (FF). The average external quantum efficiencies (EQE), measured on the best-performing devices (Figure 5), follow the same trend. The $J_{\mathrm{sc}}$ values estimated from the EQE spectra are in line with those measured under AM1.5 illumination. The noticeable difference in FF between non-fluorinated and fluorinated polymers correlates well with the higher out-ofplane mobility of P4 and P5, which allows improved charge collection. Interestingly, the polymer molecular weight turns out to have a dramatic impact on the solar cell performances despite its minor influence on the SCLC mobility. The increase in PCE is mostly due to the higher $J_{\mathrm{sc}}$ of $\mathbf{P 5}$ based devices and to a slightly larger FF. This suggests that the molecular weight affects mostly the polymer/fullerene interface, at which charge generation occurs. The further PCE enhancement observed upon using a different additive (DPE versus DIO) supports this conclusion as the latter is expected to influence principally the blend morphology. The final maximum PCE of $7.47 \%$ is among the highest values reported so far for conjugated polymers prepared by direct heteroarylation polymerization.

\section{CONCLUSION}

In this study, we have developed an efficient synthetic procedure for the synthesis of new fluorinated dithienyl-DPP (fDT-DPP) monomers and copolymers. Two classes of conjugated copolymers have been prepared by direct heteroarylation polymerization (DHAP) and tested in OFETs and PSCs. We have shown that fluorinated DPP pseudohomopolymer exhibits an ambipolar behavior in OFETs while fDT-DPP/carbazole copolymers show higher PCE than their non-fluorinated analogue. On the basis of these first examples, it is obvious that this new fDT-DPP moiety will lead to the development of new and high-performing materials for organic electronics devices. 


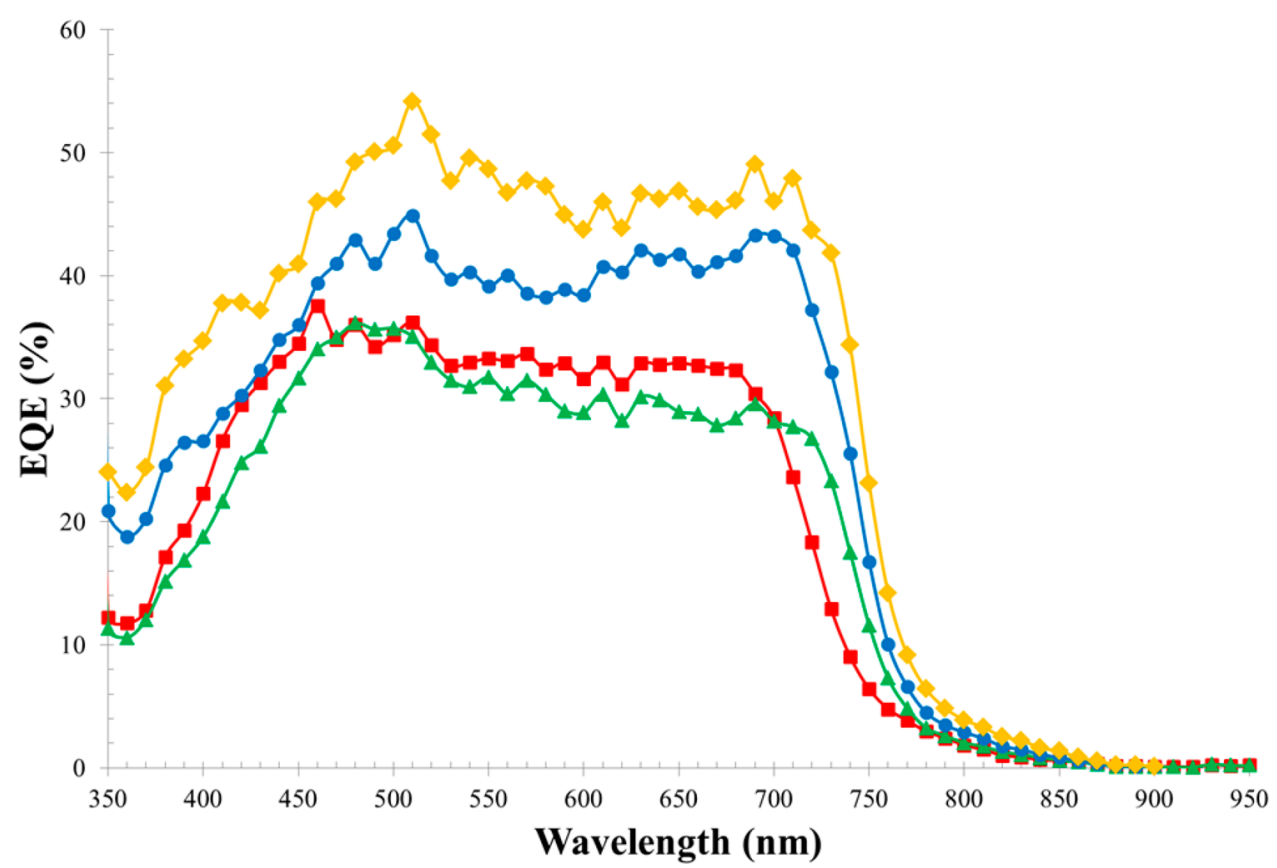

Figure 5. External quantum efficiency measured for P3 (squares), P4 (triangles) P5 with DIO (circles), and P5 with DPE (diamonds).

\section{ASSOCIATED CONTENT}

\section{S Supporting Information}

The Supporting Information is available free of charge on the ACS Publications website at DOI: 10.1021/acs.macromol.7b01198.

Figures S1-S41 (PDF)

\section{AUTHOR INFORMATION}

\section{Corresponding Author}

*E-mail: Mario.Leclerc@chm.ulaval.ca (M.L.).

\section{ORCID $\odot$}

Yuning Li: 0000-0003-3679-8133

Mario Leclerc: 0000-0003-2458-9633

\section{Author Contributions}

T. Bura and S. Beaupré contributed equally.

\section{Notes}

The authors declare no competing financial interest.

\section{ACKNOWLEDGMENTS}

The authors acknowledge the Natural Sciences and Engineering Research Council of Canada (NSERC), Université Laval (APOGÉE, Sentinelle Nord), the Canadian Institute for Advanced Research (CIFAR), and the European Fund for Regional Development (FEDER) within the framework of the program INTERREG V Rhin Supérieur and under the project no. 3.10 (PROOF) for their support. Compute Canada and Calcul Québec are also thanked for access to computational facilities. C. Roy is acknowledged for his help in the synthesis of some synthetic precursors.

\section{REFERENCES}

(1) Lu, L.; Zheng, T.; Wu, Q.; Schneider, A. M.; Zhao, D.; Yu, L. Recent Advances in Bulk Heterojunction Polymer Solar Cells. Chem. Rev. 2015, 115, 12666-12731.
(2) Etxebarria, I.; Ajuria, J.; Pacios, R. Solution-processable polymeric solar cells: A review on materials, strategies and cell architectures to overcome 10\%. Org. Electron. 2015, 19, 34-60.

(3) Sondergaard, R; Hösel, M.; Angmo, D.; Larsen-Olsen, T. T.; Krebs, F. C. Roll-to-roll fabrication of polymer solar cells. Mater. Today 2012, 15, 36-49.

(4) Hösel, M.; Dam, H. F.; Krebs, F. C. Development of Lab-to-Fab Production Equipment Across Several Length Scales for Printed Energy Technologies, Including Solar Cells. Energy Technol. 2015, 3, 293-301.

(5) Tsai, P. T.; Tsai, C. Y.; Wang, C. M.; Chang, Y. F.; Meng, H. F.; Chen, Z. K.; Lin, H. W.; Zan, H. W.; Horng, S. F.; Lai, Y. C.; Yu, P. High-efficiency polymer solar cells by blade coating in chlorine-free solvents. Org. Electron. 2014, 15, 893-903.

(6) Berny, S.; Blouin, N.; Distler, A.; Egelhaaf, H. J.; Krompiec, M.; Lohr, A.; Lozman, O. R.; Morse, G. E.; Nanson, L.; Pron, A.; Sauermann, T.; Seidler, N.; Tierney, S.; Tiwana, P.; Wagner, M.; Wilson, H. Solar Trees: First Large-Scale Demonstration of Fully Solution Coated, Semitransparent, Flexible Organic Photovoltaic Modules. Adv. Sci. 2016, 3, 1500342.

(7) Zhang, S.; Ye, L.; Hou, J. Breaking the 10\% Efficiency Barrier in Organic Photovoltaics: Morphology and Device Optimization of wellKnown PBDTTT Polymers. Adv. Energy Mater. 2016, 6, 1502529.

(8) Ouyang, X.; Peng, R.; Ai, L.; Zhang, X.; Ge, Z. Efficient polymer solar cells employing a non-conjugated small electrolyte. Nat. Photonics 2015, 9, 520-524.

(9) Zhou, H.; Zhang, Y.; Mai, C. K.; Collins, S. D.; Bazan, G. C.; Nguyen, T. Q.; Heeger, A. J. Polymer homo-tandem solar cells with best efficiency of $11.3 \%$. Adv. Mater. 2015, 27, 1767-1777.

(10) Zhao, W.; Li, S.; Yao, H.; Zhang, S.; Zhang, Y.; Yang, B.; Hou, J. Molecular Optimization enables over $13 \%$ in Organic Solar Cells. J. Am. Chem. Soc. 2017, 139, 7148-7151.

(11) Kang, I.; Yun, H. J.; Chung, D. S.; Kwon, S. K.; Kim, Y. H. Record High Hole Mobility in Polymer Semiconductors via SideChain Engineering. J. Am. Chem. Soc. 2013, 135, 14896-14899.

(12) Yun, H. J.; Kang, S. J.; Xu, Y.; Kim, S. O.; Kim, Y. H.; Noh, Y. Y.; Kwon, S. K. Dramatic Inversion of Charge Polarity in Diketopyrrolopyrrole-Based Organic Field-effect Transistors via Simple Nitrile Group Substitution. Adv. Mater. 2014, 26, 7300-7307.

(13) Choi, H.; Ko, S. J.; Kim, T.; Morin, P. O.; Walker, B.; Lee, B. H.; Leclerc, M.; Kim, J. Y.; Heeger, A. J. Small-Bandgap Polymer Solar 
Cells with Unprecedented Short-Circuit Current Density and High Fill Factor. Adv. Mater. 2015, 27, 3318-3324.

(14) Li, J.; Zhao, Y.; Tan, H. S.; Guo, Y.; Di, C. A.; Yu, G.; Liu, Y.; Lin, M.; Lim, S. H.; Zhou, Y.; Su, H.; Ong, B. S. A stable solutionprocessed polymer semiconductor with record high-mobility for printed transitors. Sci. Rep. 2012, 2, 754.

(15) Farnum, D. G.; Mehta, G.; Moore, G. G. I.; Siegal, F. P. Attempted reformatskii reaction of benzonitrile, 1,4-diketo-3,6diphenylpyrrolo[3,4-c]pyrrole. A lactam analogue of pentalene. Tetrahedron Lett. 1974, 15, 2549-2522.

(16) Wallquist, O.; Lenz, R. 20 years of DPP pigments - future perspectives. Macromol. Symp. 2002, 187, 617-629.

(17) Tieke, B.; Rabindranath, A. R.; Zhang, K.; Zhu, Y. Conjugated polymers containing diketopyrrolopyrrole units in the main chain. Beilstein J. Org. Chem. 2010, 6, 830-845.

(18) Qu, S.; Tian, H. Diketopyrrolpyrrole (DPP)-based materials for organic photovoltaics. Chem. Commun. 2012, 48, 3039-3051.

(19) Chandran, D.; Lee, K. S. Diketopyrrolopyrrole: A versatile building block for organic photovoltaic materials. Macromol. Res. 2013, 21, 272-283.

(20) Li, Y.; Sonar, P.; Murphy, L.; Hong, W. High mobility diketopyrrolopyrrole (DPP)-based organic semiconductors materials for organic thin film transistors and photovoltaics. Energy Environ. Sci. 2013, 6, 1684-1710.

(21) Naik, M. A.; Patil, S. Diketopyrrolopyrrole-based conjugated polymers and small molecules for organic ambipolar transistors and solar cells. J. Polym. Sci., Part A: Polym. Chem. 2013, 51, 4241-4260.

(22) Nielsen, C. B.; Turbiez, M.; McCulloch, I. Recent Advances in the Development of Semiconducting DPP-Containing Polymers for Transistor Applications. Adv. Mater. 2013, 25, 1859-1880.

(23) Holliday, S.; Donaghey, J. E.; McCulloch, I. Advances in Charge Carrier Mobilities of Semiconducting Polymers Used in Organic Transistors. Chem. Mater. 2014, 26, 647-663.

(24) Grzybowski, M.; Gryko, D. T. Diketopyrrolopyrrole: Synthesis, Reactivity, and Optical Properties. Adv. Opt. Mater. 2015, 3, 280-320.

(25) Yi, Z.; Wang, S.; Liu, Y. Design of High-Mobility Diketopyrrolopyrrole-Based $\pi$-Conjugated Copolymers for Organic Thin-Film Transistors. Adv. Mater. 2015, 27, 3589-3606.

(26) Jung, J. W.; Jo, J. W.; Jung, E. H.; Jo, W. H. Recent progress in high efficiency polymer solar cells by rational design and energy level tuning of low bandgap copolymers with various electron-withdrawing units. Org. Electron. 2016, 31, 149-170.

(27) Li, W.; Hendriks, K. H.; Wienk, M. M.; Janssen, R. A. J. Diketopyrrolopyrrole Polymers for Organic Solar Cells. Acc. Chem. Res. 2016, 49, 78-85.

(28) Leclerc, N.; Chavez, P.; Ibraikulov, O. A.; Heiser, T.; Lévêque, $\mathrm{P}$. Impact of Backbone Fluorination on $\pi$-conjugated Polymers in Organic Photovoltaic Devices: A Review. Polymers 2016, 8, 11.

(29) Liang, Y. Y.; Xu, Z.; Xia, J. B.; Tsai, S. T.; Wu, Y.; Li, G.; Ray, C.; Yu, L. P. For the Bright Future - Bulk Heterojunction Polymer Solar Cells with Power Conversion Efficiency of 7.4\%. Adv. Mater. 2010, 22, E135-E138.

(30) Liao, S. H.; Jhuo, H. J.; Cheng, Y. S.; Chen, S. A. Fullerene Derivative-Doped Zinc Oxide Nanofilm as the Cathode for Inverted Polymer Solar Cells with Low-Bandgap Polymer (PTB7-Th) for High Performance. Adv. Mater. 2013, 25, 4766-4771.

(31) Liu, Y.; Zhao, J.; Li, Z.; Mu, C.; Ma, W.; Hu, H.; Jiang, K.; Lin, H.; Ade, H.; Yan, H. Aggregation and morphology control enables multiple cases of high-efficiency polymer solar cells. Nat. Commun. 2014, 5, 5293-5301.

(32) Nguyen, T. L.; Choi, H.; Ko, S. J.; Uddin, M. A.; Walker, B.; Yum, S.; Jeong, J. E.; Yun, M. H.; Shin, T. J.; Hwang, S.; Kim, J. Y.; Woo, H. Y. Semi-crystalline photovoltaic polymers with efficiency exceeding $9 \%$ in a $\sim 300 \mathrm{~nm}$ thick conventional single-cell device. Energy Environ. Sci. 2014, 7, 3040-3051.

(33) Meyer, F. Fluorinated conjugated polymers in organic bulk heterojunction photovoltaic solar cells. Prog. Polym. Sci. 2015, 47, 7091.
(34) Chua, L. L.; Zaumseil, J.; Chang, J. F.; Ou, E. C. W.; Ho, P. K. H.; Sirringhaus, H.; Friend, R. H. General observation of n-type fieldeffect behavior in organic semiconductors. Nature 2005, 434, 194199.

(35) Kim, F. S.; Ahmed, E.; Subramaniyan, S.; Jenekhe, S. A. AirStable Ambipolar Field-effect Transistors and Complementary Logic Circuits from Solution-Processed n/p Polymer Heterojunctions. ACS Appl. Mater. Interfaces 2010, 2, 2974-2977.

(36) Bisri, S. Z.; Piliego, C.; Gao, J.; Loi, M. A. Outlook and Emerging Semiconducting Materials for Ambipolar Transistors. Adv. Mater. 2014, 26, 1176-1199.

(37) Irimia-Vladu, M.; Głowacki, E. D.; Troshin, P. A.; Schwabegger, G.; Leonat, L.; Susarova, D. K.; Krystal, O.; Ullah, M.; Kanbur, Y.; Bodea, M. A.; Razumov, V. F.; Sitter, H.; Bauer, S.; Sariciftci, N. S. Indigo - A Natural Pigment for High Performance Ambipolar Organic Field Effect Transistors and Circuits. Adv. Mater. 2012, 24, 375-380.

(38) Torricelli, F.; Ghittorelli, M.; Smits, E. C. P.; Roelofs, C. W. S.; Janssen, R. A. J.; Gelinck, G. H.; Kovács Vajna, Z. M.; Cantatore, E. Ambipolar Organic Tri-Gate Transistor for Low-Power Complementary Electronics. Adv. Mater. 2016, 28, 284-290.

(39) Xue, J.; Li, C.; Xin, L.; Duan, L.; Qiao, J. High-efficiency and low efficiency roll-off near-infrared fluorescent OLEDs through triplet fusion. Chem. Sci. 2016, 7, 2888-2895.

(40) Chapran, M.; Angioni, E.; Findlay, N. J.; Breig, B.; Cherpak, V.; Stakhira, P.; Tuttle, T.; Volyniuk, D.; Grazulevicius, J. V.; Nastishin, Y. A.; Lavrentovich, O. D.; Skabara, P. J. An Ambipolar BODIPY Derivative for a White Exciplex OLED and Cholesteric Liquid Crystal Laser toward Multifunctional Devices. ACS Appl. Mater. Interfaces 2017, 9, 4750-4757.

(41) Jeong, H. G.; Khim, D.; Jung, E.; Yun, J. M.; Kim, J.; Ku, J.; Jang, Y. H.; Kim, D. Y. Synthesis and characterization of an novel ambipolar polymer semiconductor based on a fumaronitrile core as an electronwithdrawing group. J. Polym. Sci., Part A: Polym. Chem. 2013, 51, $1029-1039$

(42) Wang, Z.; Li, X.; Zou, Y.; Tan, J.; Fu, X.; Liu, J.; Xiao, C.; Dong, H.; Jiang, W.; Liu, F.; Zhen, Y.; Wang, Z.; Russell, T. P.; Hu, W. Tuning charge transport from unipolar (n-type) to ambipolar in bis(naphthalene diimide) derivatives by introducing $\pi$-conjugated heterocyclic bridging moieties. J. Mater. Chem. C 2016, 4, 7230-7240.

(43) Chen, X.; Zhang, G.; Luo, H.; Li, Y.; Liu, Z.; Zhang, D. Ambipolar charge-transport property for the D-A complex with naphthalene diimide motif. J. Mater. Chem. C 2014, 2, 2869-2876.

(44) Fukuta, S.; Wu, H. C.; Koganezawa, T.; Isshiki, Y.; Ueda, M.; Chen, W. C.; Higashihara, T. Synthesis and FET characterization of novel and low-bandgap naphthalene-diimide-based semiconducting polymers. J. Polym. Sci., Part A: Polym. Chem. 2016, 54, 359-367.

(45) Nakano, M.; Osaka, I.; Takimiya, K. Naphthodithiophene Diimide (NDTI)-Based Semiconducting Copolymers: From Ambipolar to Unipolar n-Type Polymers. Macromolecules 2015, 48, 576-584.

(46) Zhou, X.; Ai, N.; Guo, Z. H.; Zhuang, F. D.; Jiang, Y.-S.; Wang, J. Y.; Pei, J. Balanced Ambipolar Organic Thin-Film Transistor Operated under Ambient Conditions: Role of the Donor Moiety in BDOPV-Based Conjugated Copolymers. Chem. Mater. 2015, 27, $1815-1820$.

(47) Zhang, G.; Ye, Z.; Li, P.; Guo, J.; Wang, Q.; Tang, L.; Lu, H.; Qiu, L. A new thieno-isoindigo derivative-based D-A polymer with very low bandgap for high-performance ambipolar organic thin-film transistors. Polym. Chem. 2015, 6, 3970-3978.

(48) Wang, X.; Choi, H. H.; Zhang, G.; Ding, Y.; Lu, H.; Cho, K.; Qiu, L. Bis(2-oxoindolin-3-ylidene)-benzodifuran-dione and bithiophene-based conjugated polymers for high performance ambipolar organic thin-film transistors: the impact of substitution positions on bithiophene units. J. Mater. Chem. C 2016, 4, 6391-6400.

(49) He, Y.; Quinn, J.; Deng, Y.; Li, Y. 3,7-Bis((E)-1-methyl-2oxoindolin-3-ylidene)-3,7-dihydrobenzo[1,2-b:4,5-b'] dithiophene-2,6(IBDT) based polymer with balanced ambipolar charge transport performance. Org. Electron. 2016, 35, 41-46.

(50) Gao, Y.; Deng, Y.; Tian, H.; Zhang, J.; Yan, D.; Geng, Y.; Wang, F. High Mobility Ambipolar Diketopyrrolopyrrole-Based Conjugated 
Polymer Synthesized Via Direct Arylation Polycondensation. Adv. Mater. 2017, 29, 1606217.

(51) Yue, W.; He, T.; Stolte, M.; Gsänger, M.; Würthner, F. Cyanated isoindigos for n-type and ambipolar organic thin film transistors. Chem. Commun. 2014, 50, 545-547.

(52) Yue, W.; Nikolka, M.; Xiao, M.; Sadhanala, A.; Nielsen, C. B.; White, A. J. P.; Chen, H. Y.; Onwubiko, A.; Sirringhaus, H.; McCulloch, I. Azaisoindigo conjugated polymers for high performance n-type and ambipolar thin film transistor applications. J. Mater. Chem. C 2016, 4, 9704-9710.

(53) Mukhopadhyay, T.; Puttaraju, B.; Senanayak, S. P.; Sadhanala, A.; Friend, R.; Faber, H. A.; Anthopoulos, T. D.; Salzner, U.; Meyer, A.; Patil, S. Air-Stable n-channel Diketopyrrolopyrrole- Diketopyrrolopyrrole Oligomers for High Performance Ambipolar Organic Transistors. ACS Appl. Mater. Interfaces 2016, 8, 25415-25427.

(54) Lin, G.; Qin, Y.; Zhang, J.; Guan, Y. S.; Xu, H.; Xu, W.; Zhu, D. Ambipolar organic field-effect transistors based on diketopyrrolopyrrole derivatives containing different $\pi$-conjugated spacers. J. Mater. Chem. C 2016, 4, 4470-4477.

(55) Jiang, T.; Xue, Z.; Ford, M.; Shaw, J.; Cao, X.; Tao, Y.; Hu, Y.; Huang, W. An ultra-low bandgap diketopyrrolopyrrole (DPP)-based polymer with balanced ambipolar charge transport for organic fieldeffect transistors. RSC Adv. 2016, 6, 78720-78726.

(56) Ji, Y.; Xiao, C.; Heintges, G. H. L.; Wu, Y.; Janssen, R. A. J.; Zhang, D.; Hu, W.; Wang, Z.; Li, W. Conjugated polymer with ternary electron-deficient units for ambipolar nanowire field-effect transistors. J. Polym. Sci., Part A: Polym. Chem. 2016, 54, 34-38.

(57) Shahid, M.; McCarthy-Ward, T.; Labram, J.; Rossbauer, S.; Domingo, E. B.; Watkins, S. E.; Stingelin, N.; Anthopoulos, T. D.; Heeney, M. Low band gap selenophene-diketopyrrolopyrrole polymers exhibiting high and balanced ambipolar performance in bottomgate transistors. Chem. Sci. 2012, 3, 181-185.

(58) Sun, B.; Hong, W.; Aziz, H.; Li, Y. A pyridine-flanked diketopyrrolopyrrole (DPP)-based donor-acceptor polymer showing high mobility in ambipolar and n-channel organic thin film transistors. Polym. Chem. 2015, 6, 938-945.

(59) Chen, Z.; Gao, D.; Huang, J.; Mao, Z.; Zhang, W.; Yu, G. Thiazole-Flanked Diketopyrrolopyrrole Polymeric Semiconductors for Ambipolar Field-Effect Transistors with Balanced Carrier Mobilities. ACS Appl. Mater. Interfaces 2016, 8, 34725-34734.

(60) Kim, J.; Han, A. R.; Hong, J.; Kim, G.; Lee, J.; Shin, T. J.; Oh, J. H.; Yang, C. Ambipolar Semiconducting Polymers with $\pi$-Spacer Linked Bis-Benzothiadiazole Blocks as Strong Accepting Units. Chem. Mater. 2014, 26, 4933-4942.

(61) Gsänger, M.; Bialas, D.; Huang, L.; Stolte, M.; Würthner, F. Organic Semiconductors based on Dyes and Color Pigments. Adv. Mater. 2016, 28, 3615-3645.

(62) Zhao, Y.; Guo, Y.; Liu, Y. 25th Anniversary Article: Recent Advances in n-Type and Ambipolar Organic Field-Effect Transistors. Adv. Mater. 2013, 25, 5372-5391.

(63) Lu, G.; Kong, X.; Ma, P.; Wang, K.; Chen, Y.; Jiang, J. Amphiphilic (Phthalocyaninato) (Porphyrinato) Europium TripleDecker Nanoribbons with Air-Stable Ambipolar OFET Performance. ACS Appl. Mater. Interfaces 2016, 8, 6174-6182.

(64) Jiang, B.; Du, C. C.; Li, M. J.; Gao, K.; Kou, L.; Chen, M.; Liu, F.; Russell, T. P.; Wang, H. Synthesis of fluorinated diphenyldiketopyrrolopyrrole derivatives as new building blocks for conjugated copolymers. Polym. Chem. 2016, 7, 3311-3324.

(65) Thompson, B. C.; Kim, Y. G.; Reynolds, J. R. Spectral Broadening in MEH-PPV:PCBM-Based Photovoltaic Devices via Blending with a Narrow Band Gap Cyanovinylene-Dioxythiophene Polymer. Macromolecules 2005, 38, 5359.

(66) Pouliot, J. R.; Sun, B.; Leduc, M.; Najari, A.; Li, Y.; Leclerc, M. A High Mobility DPP-Based Polymer Obtained via Direct(hetero)arylation Polymerization. Polym. Chem. 2015, 6, 278-282.

(67) Blouin, N.; Michaud, A.; Gendron, D.; Wakim, S.; Neagu-Plesu, R.; Belletête, M.; Durocher, G.; Tao, Y.; Leclerc, M. Towards a Rational Design of Poly(2,7-carbazole) Derivatives for Solar Cells. J. Am. Chem. Soc. 2008, 130, 732-742.
(68) Zou, Y.; Gendron, D.; Badrou-Aïch, R.; Najari, A.; Tao, Y.; Leclerc, M. A High-Mobility Low-Bandgap Poly(2,7-carbazole) Derivative for Photovoltaic Applications. Macromolecules 2009, 42, 2891-2894.

(69) Ha, J. S.; Kim, K. H.; Choi, D. H. 2,5-Bis(2-octyldodecyl)pyrrolo[3,4-c]pyrrole-1,4-(2H,5H)-dione-Based Donor-Acceptor Alternating Copolymer Bearing 5,5'-Di(thiophen-2-yl)-2,2'-biselenophene Exhibiting $1.5 \mathrm{~cm}^{2} \cdot \mathrm{V}^{-1} \cdot \mathrm{s}^{-1}$ Hole Mobility in Thin-Film Transistors. J. Am. Chem. Soc. 2011, 133, 10364-10367.

(70) Bura, T.; Beaupré, S.; Légaré, M. A.; Quinn, J.; Rochette, E.; Blaskovits, J. T.; Fontaine, F. G.; Pron, A.; Li, Y.; Leclerc, M. Direct Heteroarylation Polymerization: Guidelines for Defect-Free Conjugated Polymers. Chem. Sci. 2017, 8, 3913-3925.

(71) Roy, C.; Bura, T.; Beaupré, S.; Légaré, M. A.; Sun, J.-P; Hill, I. G.; Leclerc, M. Fluorinated Thiophene-Based Synthons: Polymerization of 1,4-dialkoxybenzene and Fluoro-Dithieno-2,1,3-benzothiadiazole by Direct Heteroarylation. Macromolecules 2017, 50, 46584667.

(72) Blaskovits, J. T.; Bura, T.; Beaupré, S.; Lopez, S.; de Goes Soares, J.; Oh, A.; Quinn, J.; Li, Y.; Aspuru-Guzik, A.; Leclerc, M. A Study of the Degree of Fluorination in Regioregular Poly(3hexylthiophene). Macromolecules 2017, 50, 162-174.

(73) Fei, F.; Boufflet, P.; Wood, S.; Wade, J.; Moriarty, J.; Gann, E.; Ratcliff, E. L.; McNeill, C. R.; Sirringhaus, H.; Kim, J.-S.; Heeney, M. Influence of Backbone Fluorination in Regioregular Poly(3-alkyl-4fluoro)thiophenes. J. Am. Chem. Soc. 2015, 137, 6866-6879.

(74) El Kassmi, A.; Fache, F.; Lemaire, M. A. Convenient Synthesis of 3-Fluorothiophene. Synth. Commun. 1994, 24, 95-101.

(75) Grenier, F.; Goudreau, K.; Leclerc, M. Robust Direct(hetero)arylation Polymerization in Biphasic Conditions. J. Am. Chem. Soc. 2017, 139, 2816-2824.

(76) Tsai, T. D.; Chang, J. W.; Wen, T. C.; Guo, T. F. Manipulating the Hysteresis in Poly(vinyl alcohol)-Dielectric Organic Field-Effect Transistors Toward Memory Elements. Adv. Funct. Mater. 2013, 23, 4206-4214.

(77) Ucurum, C.; Goebel, H.; Yildirim, F. A.; Bauhofer, W.; Krautschneider, W. Hole trap related hysteresis in pentacene fieldeffect transistors. J. Appl. Phys. 2008, 104, 084501.

(78) Egginger, M.; Bauer, S.; Schwödiauer, R.; Neugebauer, H.; Sariciftci, N. S. Current versus gate voltage hysteresis in organic field effect transistors. Monatsh. Chem. 2009, 140, 735-750. 